\title{
PENGARUH TINGKAT PEMAHAMAN MAHASISWA TERHADAP KEPUTUSAN MEMILIH JURUSAN EKONOMI DAN PERBANKAN SYARIAH (STUDI PERGURUAN TINGGI DI WILAYAH KALIMANTAN TIMUR)
}

\author{
Oleh: \\ Angrum Pratiwi \\ angrumpratiwi89@gmail.com
}

\begin{abstract}
Abstrak
Pemahaman diartikan juga perihal menguasai, mengerti, atau memahami. Pemahaman merupakan proses berpikir dan belajar, dikatakan demikian karena untuk menuju kearah pemahaman perlu diikuti dengan belajar dan berpikir secara mendalam. Pembelajaran pada fakultas ekonomi dan bisnis Islam harus menghasilkan alumni yang profesional sejalan dengan perkembangan kebutuhan sumber daya insani yang memahami ekonomi Islam dengan baik. Pembelajaran ini dilakukan dengan tujuan menghasilkan lulusan yang berakhlak, profesional, serta memahami dengan baik ilmu ekonomi dan keuangan sesuai dengan ajaran Islam. Tujuan penelitian ini adalah untuk mengetahui sejauh mana tingkat pemahaman mahasiswa terkait Ekonomi Syariah atau Perbankan Syariah di perguruan tinggi wilayah Kalimantan Timur. Mengetahui apakah terdapat pengaruh tingkat pemahaman mahasiwa terhadap keputusan memilih jurusan Ekonomi Syariah atau Perbankan Syariah di perguruan tinggi wilayah Kalimantan Timur.

Penelitian ini merupakan penelitian lapangan (field research), dengan pendekatan kuantitatif asosiatif, yaitu statistik yang berfungsi untuk menguji apakah terdapat pengaruh tingkat pemahaman terhadap keputusan memilih jurusan Ekonomi Syariah atau Perbankan Syariah. Sumber data yaitu data primer yang diperoleh langsung dari lapangan, berupa data akademik, data jumlah mahasiswa, hasil kuesioner dan data lain yang sesuai dengan tujuan penelitian. Sampel berjumlah 448 responden, yang tersebar di empat perguruan tinggi yang telah menyelenggarakan program Ekonomi Syariah atau Perbankan Syariah.
\end{abstract}


Angrum Pratiwi: Pengaruh Tingkat Pemahaman Mahasiswa Terhadap Keputusan Memilih Jurusan Ekonomi dan Perbankan Syariah (Studi Perguruan Tinggi di Wilayah Kalimantan Timur)

Variabel independen adalah tingkat pemahaman mahasiswa akan Ekonomi Syariah atau Perbankan Syariah, sedangkan variabel dependen adalah keputusan memilih jurusan ekonomi syariah atau perbankan syariah.

Hasil penelitian menunjukkan bahwa tingkat pemahaman berpengaruh positif dan siginifikan (Sig. 0.000) terhadap keputusan mahasiswa memilih jurusan/program studi ekonomi syariah atau perbankan syariah. Hasil uji determinasi menunjukkan hasil $R$ Square yaitu sebesar 0.259, artinya sebesar $25.9 \%$ tingkat pemahaman mahasiswa mampu menerangkan atau mempengaruhi keputusan memilih jurusan ekonomi atau perbankan Islam pada perguruan tinggi di Kalimantan Timur, sisanya $74.1 \%$ dipengaruhi oleh faktor lainnya yang tidak diteliti pada penelitian ini.

Kata Kunci: Tingkat Pemahaman, Keputusan Memilih, Ekonomi Syariah, dan Perbankan Syariah.

\section{Pendahuluan}

\section{A. Latar Belakang}

Salah satu kebijakan pemerintah guna mendukung pembangunan ekonomi adalah melalui pendidikan tinggi. Pendidikan tinggi sebagai bagian dari sistem pendidikan nasional memiliki peran strategis dalam mencerdaskan kehidupan bangsa dan memajukan ilmu pengetahuan dan teknologi. Untuk meningkatkan daya saing bangsa dalam menghadapi globalisasi di segala bidang, diperlukan pendidikan tinggi yang mampu mengembangkan ilmu pengetahuan dan teknologi serta menghasilkan intelektual, ilmuwan, atau profesional yang berbudaya dan kreatif, toleran, demokratis, berkarakter tangguh, serta berani membela kebenaran untuk kepentingan bangsa guna mendukung pembangunan ekonomi ${ }^{1}$.

Sementara istilah ekonomi Islam terdiri dari dua kata yaitu ekonomi dan Islam. Secara umum, bangunan ekonomi Islam didasarkan atas lima nilai universal, yaitu Tauhid (Keimanan), 'Adl (Keadilan), Nubuwwah (Kenabian), Khilafah (Pemerrintahan), dan Ma'ad (Hasil). Kelima prinsip ini menjadi dasar

1 Presiden Republik Indonesia, "Undang-Undang Republik Indonesia No. 12 Tahun 2012 Tentang Pendidikan Tinggi” (Republik Indonesia, 2012), Jakarta.h. 1.

Al Qalam: Jurnal Ilmiah Keagamaan dan Kemasyarakatan Vol. 13, No. 2, Juli-Desember 2019 
Angrum Pratiwi: Pengaruh Tingkat Pemahaman Mahasiswa Terhadap Keputusan Memilih Jurusan Ekonomi dan Perbankan Syariah (Studi Perguruan Tinggi di Wilayah Kalimantan Timur)

inspirasi untuk menyusun proposisi-proposisi dan teori-teori ekonomi Islam². Dalam ekonomi Islam, setiap keputusan ekonomi seorang manusia tidak terlepas dari nilai-nilai moral dan agama karena setiap kegiatan senantiasa dihubungkan kepada syariat. Al-qur'an menyebut ekonomi dengan istilah iqtishad (penghematan ekonomi), yang secara literal berarti 'pertengahan' atau 'moderat'. Seorang muslim dilarang melakukan pemborosan, sebagaimana firman Allah SWT dalam Surah Al-Israa' ayat 26-27. Seorang muslim diminta untuk mengambil sebuah sikap moderat dalam memperoleh dan menggunakan sumber daya. Dia tidak boleh israf (royal berlebih-lebihan), tetapi juga dilarang pelit $(b a k h l)^{3}$.

Pembelajaran pada fakultas ekonomi dan bisnis Islam harus menghasilkan alumni yang profesional sejalan dengan perkembangan kebutuhan sumber daya insani yang memahami ekonomi Islam dengan baik. Pembelajaran ini dilakukan dengan tujuan menghasilkan lulusan yang berakhlak, profesional, serta memahami dengan baik ilmu ekonomi dan keuangan sesuai dengan ajaran Islam ${ }^{4}$. Banyak upaya dilakukan pemerintah dalam hal ini lembaga perguruan tinggi baik negeri maupun swasta untuk memperkenalkan dan memberikan pembelajaran terkait ekonomi dan perbankan Islam kepada mahasiswa melalui program studi atau jurusan yang ditawarkan. Perguruan tinggi negeri maupun swasta tentunya berlomba dalam menciptakan kurikulum dan sistem pembelajaran terbaik buat mahasiswa.

Menurut Kamus Besar Bahasa Indonesia (KBBI), pemahaman diartikan sebagai proses, cara, perbuatan memahami atau memahamkan. Pemahaman

2 Adimarwan A. Karim, Ekonomi Mikro Islami (Jakarta: PT. RajaGrafindo Persada, 2007).h. 34.

${ }^{3}$ Muhammad Syafi'i Antonio, Ekonomi Islam (Bogor: STEI TAZKIA, 2010).h. 41.

4 Andri Novius, "Analisis Pemahaman Mahasiswa Akuntansi Dalam Menghadapi Mata Kuliah Dasar-Dasar Akuntansi: Studi pada Mahasiswa Akuntansi S1UIN Sultan Syarif Kasim Riau,” Fokus Ekonomi Vol. 5, no. 2 (Desember 2010): 44-60.

Al Qalam: Jurnal Ilmiah Keagamaan dan Kemasyarakatan Vol. 13, No. 2, Juli-Desember 2019 
Angrum Pratiwi: Pengaruh Tingkat Pemahaman Mahasiswa Terhadap Keputusan Memilih Jurusan Ekonomi dan Perbankan Syariah (Studi Perguruan Tinggi di Wilayah Kalimantan Timur)

diartikan juga perihal menguasai, mengerti, atau memahami ${ }^{5}$. Pemahaman merupakan proses berpikir dan belajar, dikatakan demikian karena untuk menuju kearah pemahaman perlu diikuti dengan belajar dan berpikir secara mendalam. Pemahaman diartikan juga sebagai proses, perbuatan dan cara memahami suatu disiplin ilmu tertentu. Pemahaman adalah tingkatan kemampuan yang mengharapkan seseorang mampu memahami arti atau konsep, situasi serta fakta yang diketahuinya ${ }^{6}$.

Pengambilan keputusan adalah hasil akhir dari proses pemahaman akan sebuah disiplin ilmu, memiliki dampak yang besar dalam pengambilan keputusan untuk memilih atau tidak memilih sebuah keputusan. menunjukkan bahwa terdapat beberapa pertimbangan dalam pengambilan keputusan oleh konsumen. Salah satu dasar pengambilan keputusan konsumen yaitu pertimbangan ekonomis. Pertimbangan ekonomis terkait dengan perhitungan konsumen secara ekonomis atas barang/jasa yang akan dibeli dengan perhitungan secara matang baik harga dan manfaat yang dirasakan. Pertimbangan ekonomis didasarkan pada tingkat pengetahuan dan tingkat kepercayaan dalam pengambilan keputusan ${ }^{7}$. Berdasarkan dasar teori tersebut, tingkat pengetahuan atau pemahaman berpengaruh terhadap keputusan memilih/membeli konsumen. Hal ini berangkat dari pertimbangan dasar secara ekonomis, yang memperhitungkan secara matang manfaat yang didapat konsumen.

Pertumbuhan ekonomi Kalimantan Timur tahun 2019 diperkirakan tetap tumbuh pada level positif dengan kecenderungan meningkat dibandingkan periode sebelumnya. Peningkatan pertumbuhan ekonomi Kalimantan Timur

5 Tim Penyusun Pusat Bahasa, "Kamus Bahasa Indonesia” (Jakarta: Departemen Pendidikan Nasional, 2008).h. 1102-1103.

6 Purnama Putra, "Analisis Tingkat Pemahaman Mahasiswa Terhadap Pernyataan Standar Akuntansi Keuangan Syariah PSAK - Syariah,” JRAK Vol. 6, no. No. 1 (Februari 2015): 38-50.

${ }^{7}$ Damiati, dkk, Perilaku Konsumen (Jakarta: PT. RajaGrafindo Persada, 2017).h. 162-165.

Al Qalam: Jurnal Ilmiah Keagamaan dan Kemasyarakatan Vol. 13, No. 2, Juli-Desember 2019 
Angrum Pratiwi: Pengaruh Tingkat Pemahaman Mahasiswa Terhadap Keputusan Memilih Jurusan Ekonomi dan Perbankan Syariah (Studi Perguruan Tinggi di Wilayah Kalimantan Timur)

2019 terutama didorong oleh naiknya aktivitas pada lapangan usaha konstruksi yang dipengaruhi oleh dimulainya pengerjaan konstruksi peningkatan kapasitas kilang minyak di Balikpapan ${ }^{8}$. Keberadaan perguruan tinggi di wilayah Kalimantan Timur diharap mampu mencetak sumber daya manusia yang bisa bersaing secara profesiona, kreatif, inovatif dan kompetitif guna mendukung pemerintah dalam pembangunan ekonomi daerah.

Keberadaan jurusan ekonomi dan keuangan syariah di wilayah Kalimantan Timur tidak lepas dari peran pemerintah daerah melalui Masyarakat Ekonomi Syariah (MES) dalam mendukung perkembangan ekonomi Islam di wilayah Kalimantan. Berdasarkan hasil observasi awal penulis, terdapat empat perguruan tinggi yang menyelenggarkan pendidikan ekonomi Islam, yaitu: Sekolah Tinggi Agama Islam (STAI) Ibnu Khaldun Balikpapan, menyelengarakan program studi Ekonomi Syariah dan Perbankan Syariah sejak tahun 2017 . Sekolah Tinggi Agama Islam (STAI) Sangatta, menyelenggarakan program studi Ekonomi Syariah. Sejak tahun 2014 ${ }^{10}$. Universitas Mulawarman, menyelenggarakan program studi Ekonomi Islam sejak tahun 2015 dan Institut Agama Islam Negeri (IAIN Samarinda), menyelenggarakan program studi Ekonomi Syariah dan Perbankan Syariah sejak tahun 2014. Empat perguruan tinggi tersebut berkomitmen dalam pengembangan ekonomi Islam di wilayah Kalimantan Timur guna mendukung program MES wilayah Kalimantan Timur. Tentunya tujuan perguruan tinggi untuk memberikan pemahaman, pengetahuan dan meningkatkan kesadaran masyarakat akan pentingnya ekonomi Islam, sehingga menjadi bahan pertimbangan sebagai alternatif transaksi dalam kegiatan ekonomi.

8 Kanwil BI Provinsi Kalimantan Timur, "Kajian Ekonomi dan Keuangan Regional Kalimantan Timur," Ekonomi dan Keuangan (Samarinda: Bank Indonesia, Februari 2019).h. 16-18.

${ }^{9}$ Ketua Yayasan Ibu Marwah, Jumlah Mahasiswa Aktif Jurusan/Prodi Ekonomi atau Perbankan Syariah, Tertulis, 17 Mei 2019, STAI Ibnu Khaldun Balikpapan.

${ }^{10}$ Staf Akademik Firdaus, Sistem Perkuliahan dan Jumlah Mahasiswa Aktif, Tertulis, 13 Mei 2019, STAI Sangatta Kutai Timur. 
Angrum Pratiwi: Pengaruh Tingkat Pemahaman Mahasiswa Terhadap Keputusan Memilih Jurusan Ekonomi dan Perbankan Syariah (Studi Perguruan Tinggi di Wilayah Kalimantan Timur)

Terdapat beberapa penelitian terdahulu terkait tingkat pemahaman mahasiswa terhadap keputusan memilih atau minat menjadi nasabah, yaitu Mohammad dan Mustofa (2014), melakukan penelitian dengan judul "Pengaruh Tingkat Pemahaman Agama Terhadap Perilaku Bisnis Pedagang Pasar Minggu Telaga Kabupaten Gorontalo”. Berdasarkan hasil analisis uji parsial tentang tingkat pemahaman agama tentang Iman dan Ihsan berpengaruh signifikan terhadap prilaku dagang/bisnis pedagang pasar minggu dan tingkat pemahaman agama secara bersama-sama yang terdiri dari Iman, Islam dan Ihsan berpengaruh signifikan terhadap prilaku bisnis pedagang pasar ${ }^{11}$. Mintarja, Wahab dan Masduki (2017), melakukan penelitian dengan judul "Hubungan Pengajaran Mata Kuliah Ekonomi Islam terhadap Minat Mahasiswa Menabung di Bank Syariah". Berdasarkan hasil penelitian menyimpulkan bahwa terhadap hubungan yang signifikan antara materi Ekonomi Islam, intensitas belajar, dan pemahaman mahasiswa terhadap minat menabung di Bank Syariah ${ }^{12}$. Umaryati (2017), melakukan penelitian dengan judul "Pengaruh Pembelajaran Ekonomi Islam terhadap Minat Mahasiswa Menabung di Bank Syariah”. Hasil penelitian ini menunjukkan bahwa pembelajaran Ekonomi Islam terhadap minat mahasiswa menabung di bank syariah khususnya pada mahasiswa IPS UIN Syarif Hidayatullah Jakarta memiliki pengaruh yang positif ${ }^{13}$. Kartika (2017), melakukan penelitian dengan judul "Pengaruh Pemahaman Mahasiswa Perbankan Syariah Atas Bagi Hasil Dan Bunga Terhadap Minat Menjadi Nasabah Bank Syariah Studi Kasus Mahasiswa Perbankan Syariah IAIN

11 Roni Mohammad dan Mustofa, "Pengaruh Tngkat Pemahaman Agama Terhadap Perilaku Bisnis Pedagang Pasar Minggu Telaga Kab. Gorontalo," Jurnal AlMizan Vol. 10, no. No. 1 (Juni 2014).

12 Endang Mintarja, Ahsin Abdul Wahab, dan Uki Masduki, "Hubungan Pengajaran Mata Kuliah Ekonomi Islam terhadap Minat Mahasiswa Menabung di Bank Syariah," Hayula: Indonesian Journal of Multidisciplinary Islamic Studies 1, no. 2 (Juli 2017): 189-208, https://doi.org/10.21009/hayula.001.2.04.

13 Siti Umaryati, "Pengaruh Pembelajaran Ekonomi Islam terhadap Minat Mahasiswa Menabung di Bank Syariah (Studi pada Mahasiswa IPS UIN Syarif Hidayatullah Jakarta)" (Skripsi, UIN Syarif Hidayatullah, 2017).h. iv. 
Angrum Pratiwi: Pengaruh Tingkat Pemahaman Mahasiswa Terhadap Keputusan Memilih Jurusan Ekonomi dan Perbankan Syariah (Studi Perguruan Tinggi di Wilayah Kalimantan Timur)

Surakarta Angkatan 2014-2016". Hasil menunjukkan bahwa variabel pemahaman bagi hasil dan pemahaman bunga secara simultan berpengaruh positif dan signifikan terhadap minat menjadi nasabah bank syariah. Dari ke dua variabel tersebut dapat dinyatakan secara parsial perpengaruh positif dan signifikan terhadap minat menjadi nasabah bank syariah ${ }^{14}$.

Perbedaan penelitian ini dengan penelitian terdahulu adalah objek penelitian yang digunakan yaitu perguruan tinggi negeri ataupun swasta yang menyelenggarakan jurusan/program studi Ekonomi atau Perbankan Syariah wilayah Kalimantan Timur. Terdapat empat perguruan tinggi yang dijadikan sampel penelitian, dari sekitar 40 perguruan tinggi yang tersebar di wilayah Kalimantan Timur yang menyelenggarakan jurusan/program studi Ekonomi atau Perbankan Syariah. Untuk itu penulis tertarik melakukan studi yang sama dengan kapasitas populasi dan sampel lebih banyak, serta objek penelitian baru yang belum pernah dilakukan penelitian serupa.

Beberapa penelitian terdahulu, menunjukkan bahwa variabel tingkat pemahaman berpengaruh terhadap pembelajaran mata kuliah tertentu, berpengaruh terhadap minat menabung, minat menjadi nasabah dan berpengaruh terhadap perilaku bisnis. Berdasarkan pemaparan teori, data dan penelitian terdahulu diatas menarik bagi penulis untuk melakukan penelitian lebih lanjut dan mendalam, berkaitan dengan tingkat pemahaman mahasiswa akan ekonomi dan bisnis Islam serta keputusan mereka memilih fakultas ekonomi dan bisnis Islam. Dengan ini penulis mengajukan penelitian dengan judul "Pengaruh Tingkat Pemahaman Mahasiswa Terhadap Keputusan Memilih Jurusan Ekonomi atau Perbankan Syariah (Studi Kasus Perguruan Tinggi Wilayah Kalimantan Timur)".

${ }^{14}$ Dewi Kartika, "Pengaruh Pemahaman Mahasiswa Perbankan Syariah Atas Bagi Hasil Dan Bunga Terhadap Minat Menjadi Nasabah Bank Syariah Studi Kasus Mahasiswa Perbankan Syariah IAIN Surakarta Angkatan 2014-2016" (Skripsi, IAIN Surakarta, 2017).h. xii. 
Angrum Pratiwi: Pengaruh Tingkat Pemahaman Mahasiswa Terhadap Keputusan Memilih Jurusan Ekonomi dan Perbankan Syariah (Studi Perguruan Tinggi di Wilayah Kalimantan Timur)

\section{B. Rumusan Masalah}

1. Bagaimana tingkat pemahaman mahasiswa terkait Ekonomi Syariah atau Perbankan Syariah ?

2. Apakah tingkat pemahaman mahasiswa berpengaruh terhadap keputusan memilih jurusan Ekonomi Syariah atau Perbankan Syariah ?

3. Seberapa besar pengaruh tingkat pemahaman terhadap keputusan memilih jurusan Ekonomi Syariah atau Perbankan Syariah?

\section{Landasan Teori}

\section{A. Teori Perilaku Konsumen}

Perilaku konsumen didefiniskan sebagai perilaku yang ditunjukkan konsumen untuk mencari, membeli, menggunakan, mengevaluasi, dan menghabiskan barang dan jasa guna memuaskan kebutuhan atau keinginannya. Fokus dari perilaku konsumen adalah bagaimana individu membuat keputusan untuk menghabiskan sumber-sumber yang dimilikinya dengan mengkonsumsi suatu produk. Perilaku konsumen sendiri diartikan sebagai suatu studi tentang proses pengambilan keputusan oleh konsumen dalam memilih, membeli, memakai, serta memanfaatkan barang, jasa, gagasan, atau pengalaman dalam rangka memuaskan kebutuhan dan hasrat mereka ${ }^{15}$.

Tujuan mempelajari perilaku konsumen adalah agar kita mengetahui tingkah laku, kebiasaan, karakteristik konsumen. Karena dengan mengetahui perilaku konsumen kita dapat mengetahui semua hal tentang pelanggan. Informasi tersebut kita gunakan untuk menyusun strategi atau program dalam memenuhi kebutuhan atau keinginan konsumen ${ }^{16}$. Adapun faktor-faktor yang mempengaruhi perilaku konsumen yaitu: faktor budaya (budaya, sbu budaya, kelas sosial), faktor sosial (kelompok acuan, keluarga, peran dan status), faktor pribadi (usia dan daur siklus hidup, pekerjaan dan lingkungan ekonomi, gaya

15 Freddy Rangkuti, Customer Care Excellence: Meningkatkan Kinerja Perusahaan melalui Pelayanan Prima (Jakarta: PT. Gramedia Pustaka Utama, 2016).h. 192.

${ }^{16}$ Rangkuti. Customer Care Excellence ....., h. 177. 
Angrum Pratiwi: Pengaruh Tingkat Pemahaman Mahasiswa Terhadap Keputusan Memilih Jurusan Ekonomi dan Perbankan Syariah (Studi Perguruan Tinggi di Wilayah Kalimantan Timur)

hidup, kepribadian dan konsep diri), faktor psikologi (motivasi, persepsi, pembelajaran, keyakinan dan sikap) ${ }^{17}$.

\section{B. Tingkat Pemahaman}

Menurut Kamus Besar Bahasa Indonesia (KBBI), pemahaman diartikan sebagai proses, cara, perbuatan memahami atau memahamkan. Pemahaman diartikan juga perihal menguasai, mengerti, atau memahami ${ }^{18}$. Teori pemahaman dalam teori perilaku konsumen dikenal dengan istilah Consumer Learning atau pembelajaran konsumen. Pembelajaran dapat dipandang sebagai proses dimana pengalaman menyebabkan perubahan dalam pengetahuan, sikap, atau perilaku. Pembelajaran konsumen adalah suatu perubaha dalam perilaku yang terjadi sebagai hasil dari pengalaman masa lalunya ${ }^{19}$.

Mempelajari tingkat pengetahuan/pemahaman konsumen tentang produk/jasa sangatlah penting. Dengan mengetahui tingkat pengetahuan, pemahaman dan keyakinan konsumen tentang suatu produk/jasa yang ditawarkan, maka hal tersebut akan mempengaruhi perilaku konsumen dalam memilih, menggunakan atau membeli produk/jasa. Konsumen yang mengetahui bahwa menggunakan produk/jasa tertentu bermanfaat, maka ia akan berusaha keras untuk mendapatkannya ${ }^{20}$.

Konsumen perlu mengetahui karakteristik produk/jasa agar tidak salah dalam mengambil keputusan membeli, memilih atau menggunakan, untuk itu komunikasi perusahaan/lembaga melalui berbagai macam promosi perlu dilakukan secara berkelanjutan. Berikut ini beberapa pengetahun produk/jasa yang perlu disampaikan oleh konsumen, yaitu: karakteristik produk/jasa, manfaat yang dirasakan dari produk/jasa, risiko yang timbul dari produk/jasa

\footnotetext{
${ }^{17}$ Rangkuti. Customer Care Excellence:......, h. 182-192.

${ }^{18}$ Tim Penyusun Pusat Bahasa, "Kamus Bahasa Indonesia" (Jakarta: Departemen Pendidikan Nasional, 2008).h. 1102-1103.

${ }^{19}$ Nugroho J. Setiadi, Perilaku Konsumen: Konsep dan Implikasi untu Strategis dan Penelitian Pemasaran, 1 ed. (Jakarta: Kencana, 2005).h. 185.

20 Damiati, dkk, Perilaku Konsumen (Jakarta: PT. RajaGrafindo Persada, 2017).h. 81-82.
}

Al Qalam: Jurnal Ilmiah Keagamaan dan Kemasyarakatan Vol. 13, No. 2, Juli-Desember 2019 
Angrum Pratiwi: Pengaruh Tingkat Pemahaman Mahasiswa Terhadap Keputusan Memilih Jurusan Ekonomi dan Perbankan Syariah (Studi Perguruan Tinggi di Wilayah Kalimantan Timur)

yang ditawarkan, dan sejauh mana kepuasan konsumen menggunakan produk/jasa tersebut ${ }^{21}$.

\section{Keputusan Memilih}

Dalam proses pengambilan keputusan, konsumen membutuhkan informasi dan akan melakukan berbagai upaya untuk memperoleh informasi. Pengambilan keputusan dapat dibedakan menjadi tiga tingkatan, yaitu: penyelesaian masalah ekstensif, penyelesaian masalah terbatas dan perilaku respon yang rutin. Adapun model pengambilan keputusan, yaitu masukan (memeperoleh informasi, adanya pengaruh internal atau eksternal, upaya pemasaran), upaya masuknya sosial dan budaya, proses, pengenalan kebutuhan, pencarian informasi, pencarian sebelum pembelian, pencarian internal dan eksternal, daftar merk yang diperdagangkan dan lainnya ${ }^{22}$.

Keputusan membeli yang dilakukan oleh konsumen, dipengaruhi oleh banyak hal. Pola keputusan konsumen terbentuk karena beberapa faktor, yaitu: pertama pengaruh kebudayaan, yaitu nilai-nilai atau pola perilaku budaya tertentu serta warisan dari generasi ke generasi. Kedua, kelas sosial merupakan kelompok masyarakat yang mempunyai nilai dan sikap berbeda dari kelompok lainnya. Ketiga, keluarga adalah lingkungan terdekat dengan individu dan sangat mempengaruhi nilai serta perilaku seseorang dalam membeli/memilih barang/jasa tertentu. Terakhir yaitu group-group atau komunitas yang mempengaruhi pola konsumsi konsumen. Adapaun pola konsumsi seseorang dipengaruhi beberapa faktorm yaitu usia, jenis kelamin, jabatan pekerjaan, suku dan kebangsaan, agama, jumlah pendapatan, dan pendidikan ${ }^{23}$.

\footnotetext{
${ }^{21}$ Damiati, dkk. Perilaku Konsumen ....., h. 82-89.

${ }^{22}$ Damiati, dkk. Perilaku Konsumen ....., h. 175-179.

23 Abdul Manap, Revolusi Manajemen Pemasaran, 1 ed. (Jakarta: Mitra
} Wacana Media, 2016).h.242-246. 
Angrum Pratiwi: Pengaruh Tingkat Pemahaman Mahasiswa Terhadap Keputusan Memilih Jurusan Ekonomi dan Perbankan Syariah (Studi Perguruan Tinggi di Wilayah Kalimantan Timur)

\section{Ekonomi dan Perbankan Syariah}

Menurut beberapa definisi, sistem adalah kesatuan objek yang kompleks, yang terdiri dari beberapa interaksi yang teratur dan bagian yang terpisah sehingga tertuju kepada suatu rancangan dan tujuan yang sama. Koopman dan Montias mengungkapkan, secra kesuluruhan sistem ini mencakup bidang politik, sosial termasuk orang, institusi, kumpulan, struktur organisasi, hukum dan peraturan - peraturan, termasuk semua tradisi, agama, sikap, dan nilai - nilai. Sementara istilah ekonomi Islam terdiri dari dua kata yaitu ekonomi dan Islam. Secara umum, bangunan ekonomi Islam didasarkan atas lima nilai universal, yaitu Tauhid (Keimanan), 'Adl (Keadilan), Nubuwwah (Kenabian), Khilafah (Pemerrintahan), dan Ma'ad (Hasil). Kelima prinsip ini menjadi dasar inspirasi untuk menyusun proposisi-proposisi dan teori-teori ekonomi Islam ${ }^{24}$.

Sesuai penjelasan diatas pengertian Bank Umum Syariah adalah Bank Syariah yang dalam kegiatannya memberikan jasa dalam lalu lintas pembiayaan berdasarkan prinsip hukum Islam. Adapun fungsi bank umum syariah dan unit usaha syariah sesuai dengan Undang-Undang No. 21 tahun 2008, yaitu memiliki kewajiban menjalankan fungsi dalam menghimpun dan menyalurkan dana dari masyarakat. Selain itu, bank syariah dapat menjalankan fungsi sosial untuk menerima dana yang berasal dari zakat, infak dan sedekah (ZIS) atau dana sosial lainnya ${ }^{25}$. Selain menjalankan fungsinya sebagai intermediary yaitu menyalurkan dana dari surplus dana ke pengguna dana yang membutuhkan, bank syariah juga dapat melakukan jasa perbankan kepada nasabah dengan mendapatan imbalan berupa sewa atau keuntungan. Kegiatan tersebut diantaranya jual beli valuta asing, dan ijarah.

24 Adimarwan A. Karim, Ekonomi Mikro Islami (Jakarta: PT. RajaGrafindo Persada, 2007).h. 34.

25 "Undang-Undang No. 21 Tahun 2008 Tentang Perbankan Syariah." (Republik Indonesia, 2008). 
Angrum Pratiwi: Pengaruh Tingkat Pemahaman Mahasiswa Terhadap Keputusan Memilih Jurusan Ekonomi dan Perbankan Syariah (Studi Perguruan Tinggi di Wilayah Kalimantan Timur)

\section{E. Jurusan Ekonomi dan Perbankan Syariah di Wilayah Kalimantan Timur}

Pertumbuhan ekonomi Kalimantan Timur triwulan IV 2018 tumbuh 5,14\% (yoy), meningkat dibandingkan periode sebelumnya. Kinerja positif lapangan usaha pertambangan seiring dengan optimalisasi produksi dan level harga komoditas yang masih tinggi menjadi pendorong utama ekonomi Kalimantan Timur triwulan IV 2018. Lebih lanjut, percepatan pembangunan proyek-proyek infrastruktur pemerintah pada akhir tahun 2018 turut mendukung peningkatan ekonomi Kalimantan Timur. Secara kumulatif tahunan, ekonomi Kaltim tahun 2018 tetap tumbuh positif pada level 2,67\% (yoy). Di sisi lapangan usaha, pertumbuhan ekonomi didorong oleh akselerasi lapangan usaha tambang. Optimalisasi produksi yang dilakukan oleh pelaku usaha tambang batubara untuk mencapai target 2018 menjadi pendorong pertumbuhan utama lapangan usaha ini ${ }^{26}$. Peningkatan pertumbuhan ekonomi Kaltim 2019 terutama didorong oleh naiknya aktivitas pada lapangan usaha konstruksi yang dipengaruhi oleh dimulainya pengerjaan konstruksi peningkatan kapasitas kilang minyak di Balikpapan ${ }^{27}$.

Pendidikan bagian penting untuk mendukung pertumbuhan ekonomi sebuah negara. Pendidikan merupakan pengaruh lingkungan terhadap individu untuk menghasilkan perubahan-perubahan yang tetap dalam kebiasaan perilaku, pikiran dan sikapnya. Pendidikan formal adalah pendidikan di sekolah atau perguruan tinggi yang berlangsung secara teratur dan bertingkat mengikuti aturan yang jelas. Tujuan pendidik adalah untuk memperkaya budi pekerti,

${ }^{26}$ Kanwil BI Provinsi Kalimantan Timur, "Kajian Ekonomi dan Keuangan Regional Kalimantan Timur," Ekonomi dan Keuangan (Samarinda: Bank Indonesia, Februari 2019).h. 16-18.

${ }^{27}$ Kanwil BI Provinsi Kalimantan Timur....., h. 16-18. 
Angrum Pratiwi: Pengaruh Tingkat Pemahaman Mahasiswa Terhadap Keputusan Memilih Jurusan Ekonomi dan Perbankan Syariah (Studi Perguruan Tinggi di Wilayah Kalimantan Timur)

pengetahuan dan untuk menyiapkan seseorang agar mampu dan trampil dalam suatu bidang pekerjaan tertentu ${ }^{28}$.

Perguruan tinggi di wilayah Kalimantan Timur baik negeri atau swasta berjumlah sekitar 40 perguruan tinggi, yang tersebar di wilayah Balikpapan, Samarinda, Bontang, Sangatta, Tenggarong dan Berau. Berdasarkan hasil observasi awal, hanya empat perguruan tinggi yang menyelenggarakan Jurusan/Program Studi Ekonomi atau Perbankan Syariah, yaitu Sekolah Tinggi Agama Islam (STAI) Ibnu Khaldun Balikpapan, Fakultas Ekonomi dan Bisnis Islam IAIN Samarinda, Program Studi Ekonomi Islam Universitas Mulawarman, dan Sekolah Tinggi Agama Islam (STAI) Sangatta Kutai Timur.

STAI Ibnu Khaldun Balikpapan memiliki program studi Ekonomi Syariah dan Perbankan Syariah sejak tahun 2017, jumlah mahasiswa aktif sekitar 20 orang dan perkuliahan dilaksanakan malam hari, karena sebagian besar mahasiswa telah bekerja ${ }^{29}$. STAI Sangatta Kutai Timur menyenggarakan program studi Ekonomi Islam sejak tahun 2014 dan memiliki sekitar 463 mahasiswa yang masih aktif ${ }^{30}$. Fakultas ekonomi dan Bisnis Islam IAIN Samarinda menyelenggarakan jurusan Ekonomi Syariah dan Perbankan Syariah sejak tahun 2014 dan memiliki mahasiswa sekitar 1.100 orang $^{31}$. Fakultas ekonomi dan Bisnis Universitas Mulawarman memiliki jurusan Ekonomi Islam sejak tahun 2014. Jumlah mahasiswa aktif program studi Ekonomi Islam

28 Andri Novius, "Analisis Pemahaman Mahasiswa Akuntansi Dalam Menghadapi Mata Kuliah Dasar-Dasar Akuntansi: Studi pada Mahasiswa Akuntansi S1UIN Sultan Syarif Kasim Riau," Fokus Ekonomi Vol. 5, no. 2 (Desember 2010): 44-60.

29 Ketua Yayasan Ibu Marwah, Jumlah Mahasiswa Aktif Jurusan/Prodi Ekonomi atau Perbankan Syariah, Tertulis, 17 Mei 2019, STAI Ibnu Khaldun Balikpapan.

${ }^{30}$ Staf Akademik Firdaus, Sistem Perkuliahan dan Jumlah Mahasiswa Aktif, Tertulis, 13 Mei 2019, STAI Sangatta Kutai Timur.

${ }^{31}$ Staf Akademik Dahlia, Jumlah Mahasiswa Aktif, Tertulis, 24 Mei 2019, FEBI IAIN Samarinda. 
Angrum Pratiwi: Pengaruh Tingkat Pemahaman Mahasiswa Terhadap Keputusan Memilih Jurusan Ekonomi dan Perbankan Syariah (Studi Perguruan Tinggi di Wilayah Kalimantan Timur)

berjumlah sekitar 540 orang $^{32}$. Dapat penulis simpulkan bahwa masyarakat cukup antusias untuk minta memilih jurusan/program studi Ekonomi Syariah atau Perbankan Syariah dengan melihat jumlah mahasiswa aktif, meskipun secara umum penyelenggaran jurusan/program studi Ekonomi Syariah atau Perbankan Syariah baru dimulai tahun 2014.

\section{F. Penelitian Terdahulu}

Terdapat beberapa penelitian terdahulu terkait tingkat pemahaman mahasiswa dan teori keputusan atau teori minat. Perbedaan penelitian ini dengan penelitian terdahulu adalah objek penelitian yang digunakan yaitu perguruan tinggi negeri ataupun swasta yang menyelenggarakan jurusan/program studi Ekonomi atau Perbankan Syariah wilayah Kalimantan Timur. Terdapat empat perguruan tinggi yang dijadikan sampel penelitian, dari sekitar 40 perguruan tinggi yang tersebar di wilayah Kalimantan Timur yang menyelenggarakan jurusan/program studi Ekonomi atau Perbankan Syariah. Berikut beberapa penelitian terdahulu:

Mohammad dan Mustofa (2014), melakukan penelitian dengan judul "Pengaruh Tingkat Pemahaman Agama Terhadap Perilaku Bisnis Pedagang Pasar Minggu Telaga Kabupaten Gorontalo". Hasil penelitian menunjukkan bahwa tingkat pemahaman agama yang terdiri dari Iman, Islam dan Ihsan pedagang pasar minggu Telaga tergolong tinggi. Berdasarkan hasil analisis uji parsial tentang tingkat pemahaman agama tentang Iman dan Ihsan berpengaruh signifikan terhadap prilaku dagang/bisnis pedagang pasar minggu telaga kabupaten gorontalo dan tingkat pemahaman agama tentang Islam tidak berpengaruh signifikan terhadap prilaku bisnis pedagang pasar minggu Telaga. Sedangkan tingkat pemahaman agama secara bersama-sama yang terdiri dari

32 KaProdi EKIS Isna Yuningsih, Jumlah Mahasiswa Prodi Ekonomi Islam, Online-WhatsApp, 27 Mei 2019, FEB UNMUL. 
Angrum Pratiwi: Pengaruh Tingkat Pemahaman Mahasiswa Terhadap Keputusan Memilih Jurusan Ekonomi dan Perbankan Syariah (Studi Perguruan Tinggi di Wilayah Kalimantan Timur)

Iman, Islam dan Ihsan berpengaruh signifikan terhadap prilaku bisnis pedagang pasar minggu Telaga Kabupten Gorontalo ${ }^{33}$.

Putra (2015) melakukan penelitian dengan judul "Analisis Tingkat Pemahaman Mahasiswa Terhadap Pernyataan Standar Akuntansi Keuangan Syariah Psak-Syariah". Uji beda dalam mengukur pemahaman antara mahasiswa Prodi Akuntansi peminatan Akuntansi Syariah dengan Prodi Perbankan Syariah menggunakan Mann Whitney menghasilkan nilai $p$ value sebesar 0.084 yang berada dibawah nilai batas kritis yaitu 0.05 berarti bahwa tidak ada perbedaan yang signifikan tingkat pemahaman keduanya. Walaupun hasil ini belum bisa menjelaskan kemampuan kognitif yang digunakan dalam melakukan evaluasi pembelajaran namun mampu memberikan rekomendasi kepada pengajar agar mahasiswa lebih memahami terutama pada tahap "mengerti" dan "memberi contoh" dengan memberikan contoh yang lebih aplikatif dalam pembelajarannya ${ }^{34}$.

Mintarja, Wahab dan Masduki (2017), melakukan penelitian dengan judul "Hubungan Pengajaran Mata Kuliah Ekonomi Islam terhadap Minat Mahasiswa Menabung di Bank Syariah”. Jenis penelitian ini adalah penelitian deskriptif-kuantitatif. Penelitian deskriptif menjelaskan fenomena yang terjadi yang berkaitan dengan variabel penelitian. Berdasarkan hasil penelitian menyimpulkan bahwa terhadap hubungan yang signifikan antara materi Ekonomi Islam, intensitas belajar, dan pemahaman mahasiswa terhadap minat menabung di Bank Syariah ${ }^{35}$.

33 Roni Mohammad dan Mustofa, "Pengaruh Tngkat Pemahaman Agama Terhadap Perilaku Bisnis Pedagang Pasar Minggu Telaga Kab. GorontaloP,” Jurnal AlMizan Vol. 10, no. No. 1 (Juni 2014).

${ }^{34}$ Purnama Putra, "Analisis Tingkat Pemahaman Mahasiswa Terhadap Pernyataan Standar Akuntansi Keuangan Syariah PSAK - Syariah," JRAK Vol. 6, no. No. 1 (Februari 2015): 38-50.

35 Endang Mintarja, Ahsin Abdul Wahab, dan Uki Masduki, "Hubungan Pengajaran Mata Kuliah Ekonomi Islam terhadap Minat Mahasiswa Menabung di Bank 
Angrum Pratiwi: Pengaruh Tingkat Pemahaman Mahasiswa Terhadap Keputusan Memilih Jurusan Ekonomi dan Perbankan Syariah (Studi Perguruan Tinggi di Wilayah Kalimantan Timur)

Umaryati (2017), melakukan penelitian dengan judul "Pengaruh Pembelajaran Ekonomi Islam terhadap Minat Mahasiswa Menabung di Bank Syariah”. Hasil penelitian ini menunjukkan bahwa pembelajaran Ekonomi Islam terhadap minat mahasiswa menabung di bank syariah khususnya pada mahasiswa IPS UIN Syarif Hidayatullah Jakarta memiliki pengaruh yang positif, berdasarkan tabel anova, diperoleh nilai Sig. $=0,027$ yang berarti $<$ taraf signifikansi $(0,05)$ atau Ho ditolak, adalah signifikannya dan berpola linear yang berarti jika pemahaman tentang bank syariah dalam pembelajaran Ekonomi Islam bertambah satu satuan maka minat menabung di bank syariah meningkat senilai $28,9 \%$. Adanya pengaruh pembelajaran Ekonomi Islam terhadap minat menabung di bank syariah mengandung pengertian bahwa semakin besar pemahaman tentang bank syariah dalam pembelajaran Ekonomi Islam, maka akan semakin besar minat mahasiswa menabung di bank syariah ${ }^{36}$.

Kartika (2017), melakukan penelitian dengan judul "Pengaruh Pemahaman Mahasiswa Perbankan Syariah Atas Bagi Hasil Dan Bunga Terhadap Minat Menjadi Nasabah Bank Syariah Studi Kasus Mahasiswa Perbankan Syariah IAIN Surakarta Angkatan 2014-2016". Sampel penelitian sejumlah 86 mahasiswa perbankan syariah IAIN Surakarta tahun angkatan 2014-2016. Hasil menunjukkan bahwa variabel pemahaman bagi hasil dan pemahaman bunga secara simultan berpengaruh positif dan signifikan terhadap minat menjadi nasabah bank syariah. Dari ke dua variabel tersebut dapat dinyatakan secara parsial perpengaruh positif dan signifikan terhadap minat menjadi nasabah bank syariah ${ }^{37}$.

Syariah," Hayula: Indonesian Journal of Multidisciplinary Islamic Studies 1, no. 2 (Juli 2017): 189-208, https://doi.org/10.21009/hayula.001.2.04.

36 Siti Umaryati, "Pengaruh Pembelajaran Ekonomi Islam terhadap Minat Mahasiswa Menabung di Bank Syariah (Studi pada Mahasiswa IPS UIN Syarif Hidayatullah Jakarta)" (Skripsi, UIN Syarif Hidayatullah, 2017).h. iv.

37 Dewi Kartika, "Pengaruh Pemahaman Mahasiswa Perbankan Syariah Atas Bagi Hasil Dan Bunga Terhadap Minat Menjadi Nasabah Bank Syariah Studi Kasus 
Angrum Pratiwi: Pengaruh Tingkat Pemahaman Mahasiswa Terhadap Keputusan Memilih Jurusan Ekonomi dan Perbankan Syariah (Studi Perguruan Tinggi di Wilayah Kalimantan Timur)

\section{G. Hipotesis Penelitian}

Pemahaman diartikan sebagai proses, cara, perbuatan memahami atau memahamkan. Pemahaman diartikan juga perihal menguasai, mengerti, atau memahami ${ }^{38}$. Teori pemahaman dalam teori perilaku konsumen dikenal dengan istilah Consumer Learning atau pembelajaran konsumen. Pembelajaran dapat dipandang sebagai proses dimana pengalaman menyebabkan perubahan dalam pengetahuan, sikap, atau perilaku ${ }^{39}$. Ada beberapa dasar dalam pembelajaran, yaitu: pertama adalah motivasi, keadaan seseorang pada waktu dihadapkan dengan informasi baru akan menimbulkan pengaruh besar sekali pada apa yang diingat. Kedua adalah penguatan, hal ini muncul ketika konsumen berperilaku yang sama seperti sebelumnya, dan mendapatkan respon positif atas tindakannya ${ }^{40}$.

Keputusan membeli yang dilakukan oleh konsumen, dipengaruhi oleh banyak hal. Pola keputusan konsumen terbentuk karena beberapa faktor, yaitu: pertama pengaruh kebudayaan, yaitu nilai-nilai atau pola perilaku budaya tertentu serta warisan dari generasi ke generasi. Kedua, kelas sosial merupakan kelompok masyarakat yang mempunyai nilai dan sikap berbeda dari kelompok lainnya. Ketiga, keluarga adalah lingkungan terdekat dengan individu dan sangat mempengaruhi nilai serta perilaku seseorang dalam membeli/memilih barang/jasa tertentu ${ }^{41}$.

Berdasarkan teori diatas dapat penulis tarik kesimpulan bahwa tingkat pemahaman memiliki hubungan atau pengaruh terhadap keputusan untuk membeli/memilih barang/jasa. Beberapa penelitian terdahulu mendukung teori diatas, yaitu penelitian yang dilakukan oleh Mohammad dan Mustofa (2014),

Mahasiswa Perbankan Syariah IAIN Surakarta Angkatan 2014-2016" (Skripsi, IAIN Surakarta, 2017).h. xii.

${ }^{38}$ Tim Penyusun Pusat Bahasa, "Kamus Bahasa Indonesia.” ....., h. 1102-1103.

39 Setiadi, Perilaku Konsumen: Konsep dan Implikasi untu Strategis dan Penelitian Pemasaran....., h. 185.

${ }^{40}$ Setiadi. Perilaku Konsumen ....., h. 186-187

${ }^{41}$ Manap, Revolusi Manajemen Pemasaran....., h.242-246. 
Angrum Pratiwi: Pengaruh Tingkat Pemahaman Mahasiswa Terhadap Keputusan Memilih Jurusan Ekonomi dan Perbankan Syariah (Studi Perguruan Tinggi di Wilayah Kalimantan Timur)

Mintarja, Wahab dan Masduki (2017), dan Hariyago dan Suprianto (2011), Umaryati (2017), dan Kartika (2017), menunjukkan bahwa tingkat pemahaman memiliki pengaruh terhadap keputusan membeli atau minat menjadi nasabah, maka hipotesis yang penulis ajukan pada penelitian ini adalah:

$\mathrm{H}_{1}=$ Terdapat pengaruh tingkat pemahaman mahasiswa terhadap keputusan memilih jurusan ekonomi atau perbankan Syariah.

\section{H. Kerangka Penelitian}

Penelitian ini menggunakan variabel independen yaitu tingkat pemahaman dan minat menjadi mahasiswa jurusan ekonomi atau perbankan Islam sebagai variabel dependen. Adapun wawancara di beberapa perguruan tinggi sebagai penguat penelitian dalam menarik kesimpulan dan pemberian saran penelitian. Berikut kerangka penelitian yang tercermin dalam Gambar 3.1:

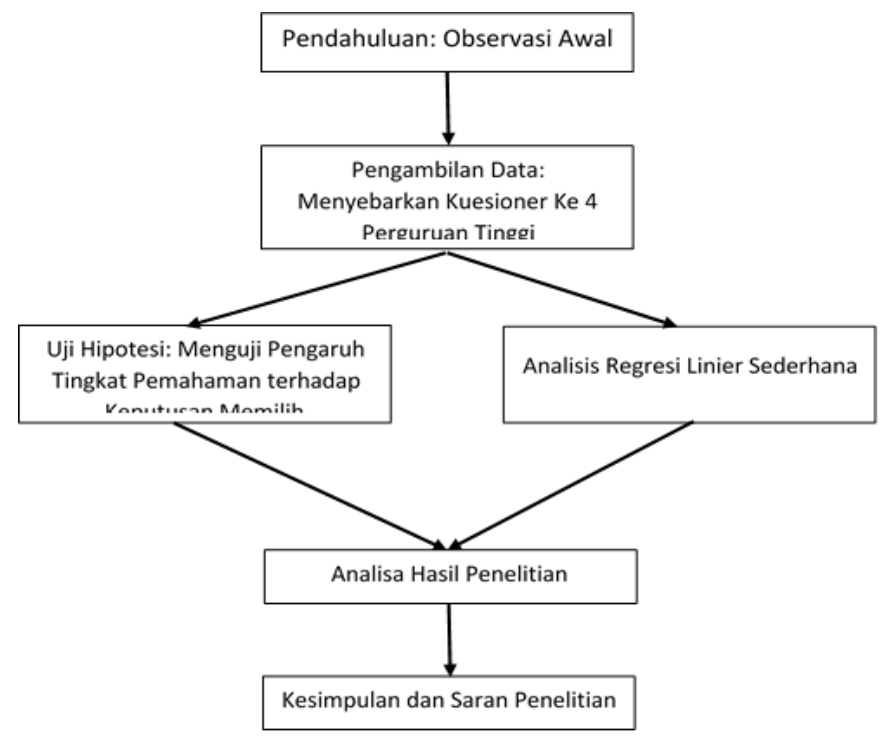

Gambar 2.1

Kerangka Penelitian

Sumber: Penulis, 2019 
Angrum Pratiwi: Pengaruh Tingkat Pemahaman Mahasiswa Terhadap Keputusan Memilih Jurusan Ekonomi dan Perbankan Syariah (Studi Perguruan Tinggi di Wilayah Kalimantan Timur)

\section{Metode Penelitian}

\section{A. Jenis Penelitian}

Adapun jenis penelitian yang digunakan dalam penelitian ini menurut tempatnya tergolong ke dalam penelitian lapangan (field research), yaitu penelitian yang bertujuan untuk mengetahui latar belakang keadaan sekarang, dan interaksi lingkungan suatu unit sosial, baik individu, kelompok, lembaga atau masyarakat yang berada dalam objek penelitian ${ }^{42}$. Penelitian lapangan dilakukan untuk mendapatkan data berupa tingkat pengetahuan mahasiswa terhadap keputusan memilih jurusan ekonomi Islam pada perguruan tinggi yang tersebar di wilayah Kalimantan Timur.

Jika dilihat dari teknik analisis data, maka penelitian ini tergolong ke dalam penelitan deskriptif kuantitatif, yaitu statistik yang berfungsi untuk mendeskripsikan atau memberi gambaran terhadap obyek yang diteliti melalui data sampel atau populasi, tanpa melakukan analisis dan membuat kesimpulan yang berlaku ${ }^{43}$. Penelitian ini bersifat deskriptif, maka dimaksudkan untuk memaparkan dan menggambarkan semua peristiwa dan pengalaman yang dialami penulis selama melakukan penelitian, mengumpulkan informasi serta data yang diperlukan dalam penelitian secara lengkap dan ojektif, baik itu informasi atau data yang didengar, dilihat, dan dicatat oleh penulis.

\section{B. Jenis dan Sumber Data}

Jenis data yang digunakan adalah data kuantitatif, yaitu data yang diukur dalam suatu skala numerik (angka). Sumber data yang digunakan adalah data sekunder, yaitu data yang telah dikumpulkan oleh pihak lainnya ${ }^{44}$. Penelitian ini menggunakan dua jenis sumber data yaitu data sekunder yang diperoleh tidak langsung dari subjek penelitian, dikumpulkan dan disajikan oleh

\footnotetext{
42 V. Wiratna Sujarweni, Kupas Tuntas Penelitian Akuntansi Dengan SPSS (Yogyakarta: Pustaka Baru Pers, 2016).h. 47-49

43 Suliyanto, Metode Penelitian Bisnis: Untuk Skripsi, Tesis dan Desertasi (Yogyakarta: ANDI, 2018).h. 177.

${ }^{44}$ Suliyanto. Metode Penelitian Bisnis ......, h. 155.
} 
Angrum Pratiwi: Pengaruh Tingkat Pemahaman Mahasiswa Terhadap Keputusan Memilih Jurusan Ekonomi dan Perbankan Syariah (Studi Perguruan Tinggi di Wilayah Kalimantan Timur)

pihak lain. Data primer yaitu data yang dikumpulkan sendiri oleh peneliti langsung dari sumber pertama ${ }^{45}$.

Data sekunder penelitian ini berupa hasil dokumentasi, laporan dan arsip jumlah mahasiswa serta proses belajar mengajar di perguruan tinggi yang menjadi objek penelitian. Data primer diperoleh dengan cara menyebarkan angket langsung ke mahasiswa, untuk memperoleh data terkait tingkat pemehaman dan keputusan memilih jurusan atau program studi Ekonomi Syariah atau Perbankan Syariah.

\section{Populasi dan Sampel Penelitian}

Populasi merupakan wilayah generalisasi yang terdiri atas objek/subjek yang mempunyai kualitas dan karakteristik tertentu yang ditetapkan oleh penulis untuk dipelajari dan kemudian ditarik kesimpulannya. Populasi juga diartikan sebagai keseluruhan elemen yang hendak diduga karakteristiknya ${ }^{46}$. Adapun populasi dalam penelitian ini yaitu seluruh mahasiswa jurusan ekonomi syariah atau perbankan syariah pada perguruan tinggi yang berada di wilayah Kalimantan Timur.

Penelitian ini menggunakan sampel dengan alasan adalah meningkatkan efisiensi penelitian dan meningkatkan ketelitian penelitian ${ }^{47}$. Sampel adalah bagian dari populasi yang mewakili jumlah dan karakteristik dari populasi tersebut. Kerangka sampel merupakan daftar yang berisi elemen-elemen yang ada dalam populasi. Penentuan ukuran sampel berdasarkan analisis statistik menggunakan rumus slovin $^{48}$.

Berdasarkan hasil observasi awal diketahui bahwa jumlah populasi mahasiswa yang mengambil jurusan ekonomi syariah dan perbankan syariah

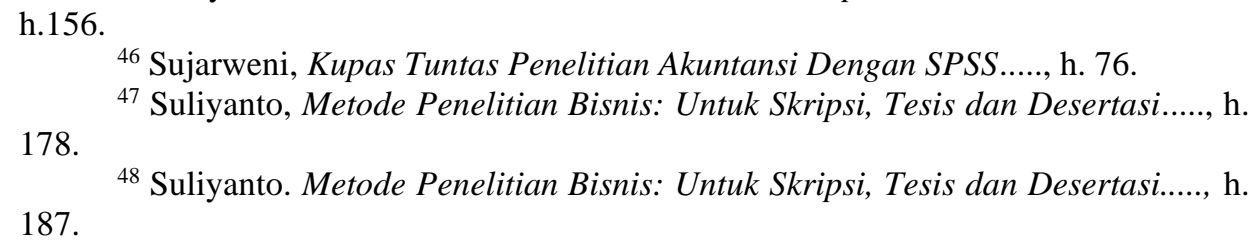

${ }^{46}$ Sujarweni, Kupas Tuntas Penelitian Akuntansi Dengan SPSS....., h. 76.

${ }^{47}$ Suliyanto, Metode Penelitian Bisnis: Untuk Skripsi, Tesis dan Desertasi....., h. 178.

${ }^{48}$ Suliyanto. Metode Penelitian Bisnis: Untuk Skripsi, Tesis dan Desertasi....., h. 187.

${ }^{45}$ Suliyanto. Metode Penelitian Bisnis: Untuk Skripsi, Tesis dan Desertasi......, 
Angrum Pratiwi: Pengaruh Tingkat Pemahaman Mahasiswa Terhadap Keputusan Memilih Jurusan Ekonomi dan Perbankan Syariah (Studi Perguruan Tinggi di Wilayah Kalimantan Timur)

yang tersebar di empat perguruan tinggi yaitu STAI Ibnu Khaldun Balikpapan (20 mahasiswa), STAI Sangatta (463 mahasiswa), FEBI IAIN Samarinda (1.100 mahasiswa), dan Universitas Mulawarman (501 mahasiswa). Total berjumlah sekitar 2.084 mahasiswa aktif dari empat perguruan tinggi tersebut. Beradasarkan perhitungan menggunakan rumus Slovin dengan tingkat kesalahan 5\%, maka ukuran sampel minimal yang harus diambil adalah sebanyak 336 sampel. Total responden yang mengisi kuesioner yaitu berjumlah 448 responden yang berasal dari empat perguruan tinggi diatas.

\section{Teknik Pengumpulan Data}

\section{Kueisoner}

Kueisoner dalam penelitian ini diberikan kepada mahasiswa jurusan ekonomi syariah atau perbankan syariah pada perguruan tinggi di wilayah Kalimantan Timur. Kuesioner yang digunakan adalah model kuesioner tertutup karena jawaban telah disediakan dan pengukurannya menggunakan skala likert. Skala likert digunakan untuk mengukur sikap, pendapat, dan persepsi seseorang atau sekelompok orang tentang fenomena sosial $^{49}$.

Sebelum membuat daftar pertanyaan terlebih dahulu membuat instrumen dengan menjabarkan variabel menjadi sub variabel yang akan diukur, hal ini digunakan sebagai patokan untuk menyusun instrumen yang berupa pertanyaan atau pernyataan instrumen yang menggunakan skala likert mempunyai gradasi dari sangat negatif sampai sangat positif dengan 5 (lima) alternatif jawaban, dengan jawaban masing-masing: Sangat Tidak Setuju, Tidak Setuju, Kurang Setuju, Setuju dan Sangat Setuju.

\section{Wawancara}

Tujuan dilakukan wawancara adalah untuk mengetahui secara mendalam terkait jumlah mahasiswa, asal dan latar belakang sebagian 93.

${ }^{49}$ Sugiyono, Metode Penelitian Manajemen, 4 ed. (Bandung: Alfabeta, 2015).h. 
Angrum Pratiwi: Pengaruh Tingkat Pemahaman Mahasiswa Terhadap Keputusan Memilih Jurusan Ekonomi dan Perbankan Syariah (Studi Perguruan Tinggi di Wilayah Kalimantan Timur)

besar mahasiswa, bagaiaman proses belajar mengajar, mata kuliah yang diajarkan dan pengembangan perguruan tinggi kedepannya. Wawancara dilakukan kepada ketua jurusan atau ketua program studi ekonomi syariah atau perbankan syariah pada perguruan tinggi di wilayah Kalimantan Timur. Berdasarkan hasil observasi awal diperoleh empat perguruan tinggi yang memiliki program studi/jurusan ekonomi syariah atau perbankan syariah, yaitu: STAI Ibnu Khaldun Balikpapan, STAI Sangatta, FEBI IAIN Samarinda, dan Fakultas Ekonomi Bisnis Universitas Mulawarman.

\section{Dokumentasi}

Teknik dokumentasi dilakukan dengan cara mempelajari bukubuku, literatur-literatur dan jurrnal penelitian yang terdapat di web yang berhubungan dengan perumusan masalah yang diteliti ${ }^{50}$. Dalam hal ini penulis mengumpulkan berbagai sumber data, laporan, artikel atau berita terkait perguruan tinggi di Kalimantan Timur yang memiliki program studi/jurusan ekonomi syariah atau perbankan syariah.

\section{Observasi Awal}

Observasi awal dilakukan di empat perguruan tinggi yang berbeda di wilayah Kalimantan Timur. Pada tanggal 10 dan 16 Mei 2019, dilakukan observasi awal ke STAI Ibnu Khaldun Balikpapan. Hasil survei menunjukkan bahwa STAI Ibnu Khaldun Balikpapan merupakan lembaga pendidikan swasta dengan jenjang pendidikan dari SD sampai dengan Perguruan Tinggi. Perguruan tinggi memiliki program studi ekonomi syariah dan perbankan syariah dengan jumlah mahasiswa semester awal sekitar 20 orang. Proses perkuliahan dilakukan malam hari, pukul 19.0022.00 WITA karena sebagian besar mahasiswa dengan latar belakang pegawai.

\footnotetext{
${ }^{50}$ Sujarweni, Kupas Tuntas Penelitian Akuntansi Dengan SPSS..... h. 93.
} 
Angrum Pratiwi: Pengaruh Tingkat Pemahaman Mahasiswa Terhadap Keputusan Memilih Jurusan Ekonomi dan Perbankan Syariah (Studi Perguruan Tinggi di Wilayah Kalimantan Timur)

Pada tanggal 13 dan 20 Mei 2019, dilakukan survei awal ke STAI Sangatta Kutai Timur. Hasil survei menunjukkan bahwa STAI Sangatta merupakan perguruan tinggi swasta yang mendapatkan bantuan dana APBD dari pemerintah daerah dalam pengelolaan perguruan tinggi. Terdapat dua jurusan yaitu Tarbiyah dan Syariah, jurusan syariah memiliki program studi Ekonomi Syariah dengan jumlah mahasiswa semester awal sekitar 463 orang. Proses belajar mengajar diberlakukan kelas reguler hari Senin-Kamis dan kelas weekend hari Jum'at dan Sabtu. Latar belakang mahasiswa berasal dari SMA dan SMK yang berada di wilayah Sangatta dan sekitarnya. Tenaga pendidik berasal dari Sangatta dan Samarinda.

Sedangkan survei di Univeristas Mulawarman dilakukan dengan korespondensi via media sosial dengan salah satu dosen dan mahasiwa jurusan ekonomi syariah. Informasi yang didapatkan bahwa jumlah mahasiswa semester awal jurusan ekonomi Syariah berjumlah 510 orang, dengan latar belakang pendidikan SMA, SMK, atau MAN dari beberapa wilayah Kalimantan Timur. Sedangkan, informasi yang didapat dari bidang akademik Fakultas Ekonomi dan Bisnis Islam IAIN Samarinda, jumlah mahasiswa semester awal jurusan ekonomi syariah dan perbankan syariah berjumlah sekitar 1.100 orang. Latar belakang pendidikan sangat beragam yaitu SMA, SMK, MAN dan Pondok Pesantren, serta berasal dari beberapa wilayah di Kalimantan Timur. Berdasarkan hasil survei awal, menunjukkan bahwa jumlah mahasiwa jurusan ekonomi syariah atau perbankan syariah cukup banyak dari empat perguruan tinggi tersebut. Artinya, jurusan/program studi ekonomi syariah atau perbankan syariah menjadi alternatif pilihan mahasiswa untuk mempelajari ekonomi Islam.

\section{E. Variabel dan Instrumen Penelitian}

Variabel independen atau variabel bebas adalah variabel yang mempengaruhi atau menjadi sebab perubahannya atau timbulnya variabel 
Angrum Pratiwi: Pengaruh Tingkat Pemahaman Mahasiswa Terhadap Keputusan Memilih Jurusan Ekonomi dan Perbankan Syariah (Studi Perguruan Tinggi di Wilayah Kalimantan Timur)

dependen (terikat) ${ }^{51}$. Variabel independen penelitian ini adalah tingkat pemahaman. Pemahaman adalah proses yang ditempuh oleh seseorang untuk mengartikan sebuah objek. Pemahaman bertujuan untuk melihat kemampuan seseorang dalam menjawab pertanyaan yang disampaikan. Tingkat pemahaman mahasiswa diukur dengan pemahaman akan agama Islam, pengetahuan akan ekonomi atau perbankan Islam, memahami konsep riba, mengetahui sejarah dan dasar hukum ekonomi atau perbankan Islam, mengikuti perkembangan terkini tentang ekonomi atau perbankan Islam dan mengetahui jurusan ekonomi atau perbankan Islam dari keluarga, sahabat, atau media sosial lainnya.

Variabel dependen (terikat) merupakan variabel yang dipengaruhi atau yang menjadi akibat, karena adanya variabel bebas ${ }^{52}$. Variabel dependen penelitian ini yaitu keputusan memilih, variabel ini tidak lepas dari teori perilaku konsumen yaitu adanya ketertarikan atau minat akan suatu hal. Adapun indikator keputusan memilih penelitian ini adalah telah mengetahui ekonomi atau perbankan Islam, menjadi anggota atau nasabah di lembaga keuangan atau lainnya yang berbasis syariah, memahami sistem bunga dan bagi hasil, merasa terpanggil untuk mempelajari lebih dalam, berkomitmen meninggalkan ekonomi atau perbankan yang berbau riba, memutuskan untuk kuliah di jurusan ekonomi atau perbankan Islam, memiliki harapan besar dan komitmen untuk mengembangkan ekonomi atau perbankan Islam.

\section{F. Uji Instrumen Data}

\section{Uji Validitasi}

Validitas adalah ketetapan atau kecermatan suatu instrument dalam mengukur apa yang diukur. Data dikatakan valid jika pertanyaan pada kuisoner mampu mengungkapkan sesuatu yang

${ }^{51}$ Sugiyono, Metode Penelitian Kuantitatif, Kualitatif dan $R \&$ D..... h. 39.

${ }^{52}$ Sugiyono. Metode Penelitian..., h. 40. 
Angrum Pratiwi: Pengaruh Tingkat Pemahaman Mahasiswa Terhadap Keputusan Memilih Jurusan Ekonomi dan Perbankan Syariah (Studi Perguruan Tinggi di Wilayah Kalimantan Timur)

diukur oleh kuisoner tersebut ${ }^{53}$. Hasil $r$ hitung dibandingkan dengan $r$ tabel di mana df = n-2 dengan sig $5 \%$. Jika $r$ tabel $<\mathrm{r}$ hitung maka dikatakan valid. Uji validitas menggunakan teknik Pearson Correlation $^{54}$.

2. Uji Reliabilitas

Realibilitas instrument menunjukkan kemampuan alat ukur untuk menghasilkan pengukuran yang dapat dipercaya. Kuesioner yang digunakan setidaknya memenuhi syarat reliabel, artinya bahwa alat ukur tersebut mampu mengungkapkan data yang cukup dapat dipercaya. Uji reliabilitas kali ini menggunakan metode Alpha Cronbach, instrumen variabel dikatan reliabel jika nilai Alpha Cronbach $>0,60^{55}$.

\section{G. Teknik Analisis Data}

\section{Uji Asumsi Klasik}

a. Uji Normalitas, uji ini untuk menguji apakah dalam model regesi, variabel teikat dan variabel bebas keduanya mempunyai distribusi secara normal atau tidak, uji ini menggunakan Kolmogrov Smirnov. Jika signifikan > 0,05 maka variabel berdistribusi normal dan sebaliknya jika signifikan $<0,05$ maka variabel tidak berdistribusi normal ${ }^{56}$.

b. Uji Autokorelasi, uji ini dilakukan untuk mengetahui ada tidaknya korelasi antara variabel pengganggu pada periode tertentu dengan periode sebelumnya. Jika, terjadi korelasi

\footnotetext{
${ }^{53}$ Imam Ghozali, Aplikasi Analisis Multivariate Dengan Program IBM SPSS 21: Update PLS Regresi, 7 ed. (Semarang: Badan Penerbit UNDIP, 2013).h. 52.

${ }^{54}$ Sujarweni, Kupas Tuntas Penelitian Akuntansi Dengan SPSS....., h. 108.

${ }^{55}$ Suliyanto, Metode Penelitian Bisnis: Untuk Skripsi, Tesis dan Desertasi..... h. 265.

56 Ghozali, Aplikasi Analisis Multivariate Dengan Program IBM SPSS 21: Update PLS Regresi..... h. 160.
} 
Angrum Pratiwi: Pengaruh Tingkat Pemahaman Mahasiswa Terhadap Keputusan Memilih Jurusan Ekonomi dan Perbankan Syariah (Studi Perguruan Tinggi di Wilayah Kalimantan Timur)

maka terjadi gejala autokorelasi. Mendeteksi autokorelasi dengan menggunakan nilai Durbin Watson ${ }^{57}$.

c. Uji Heteroskedastisitas, uji heteroskedastisitas adalah suatu keadaan di mana varians dan kesalahan pengganggu tidak konstan untuk semua variabel bebas. Model regresi yang baik tidak terjadi heteroskedastisitas. Uji yang digunakan untuk melihat gejala ini menggunakan uji Glejser, hasilnya apabila nilai probabilitas signifikansinya lebih besar dari 5\% (> 0,05), berarti tidak terjadi gejala heterokedastisitas dan sebaliknya apabila level di bawah signifikan $(<0,05)$ berarti terjadi heterokedastisitas ${ }^{58}$.

\section{Analisis Regresi Linier Sederhana}

Analisis yang digunakan dalam penelitian ini adalah analisis regresi, yaitu suatu teknik yang digunakan untuk membangun suatu persamaan yang menghubungkan antara variabel terikat dengan variabel bebas sekaligus untuk menentukan nilai ramalan atau dugaan. Adapun pengujian hipotesis menggunakan model analisis regresi sederhana, karena variabel independen (bebas) yang digunakan hanya terdapat satu variabel. Secara umum persamaan regresi sederhana dapat dirumuskan sebagai berikut ${ }^{59}$ :

$\mathrm{Y}=\mathrm{a}+\mathrm{b} \mathrm{X}+\mathrm{e}$

$\mathrm{Y}=$ Nilai yang diramalkan

$\mathrm{a}=$ Nilai intercept/konstanta

$\mathrm{b}=$ Koefisien regresi

$\mathrm{X}=$ Variabel bebas

$\mathrm{E}=$ Nilai residu

${ }^{57}$ Ghozali. Aplikasi Analisis Multivariate......., h. 110.

${ }^{58}$ Ghozali. Aplikasi Analisis Multivariate....., h. 142.

59 Suliyanto, Ekonometrika Terapan: Teori \& Aplikasi dengan SPSS (Yogyakarta: ANDI, 2011).h. 37-39.

Al Qalam: Jurnal Ilmiah Keagamaan dan Kemasyarakatan Vol. 13, No. 2, Juli-Desember 2019 
Angrum Pratiwi: Pengaruh Tingkat Pemahaman Mahasiswa Terhadap Keputusan Memilih Jurusan Ekonomi dan Perbankan Syariah (Studi Perguruan Tinggi di Wilayah Kalimantan Timur)

Dimana a dan b dicari dengan rumus:

$$
\begin{aligned}
& \mathrm{b}=\frac{\left(\sum Y\right)}{n}-\frac{b\left(\sum X\right)}{n} \\
& \mathrm{a}=\frac{n\left(\sum X Y\right)}{n\left(\sum X^{2}\right)}-\frac{\left(\sum X\right)\left(\sum Y\right)}{n\left(\sum X\right)^{2}}
\end{aligned}
$$

\section{Pengujian Hipotesis}

\section{a. Koefisiensi Determinasi $\left(R^{2}\right)$}

Koefisiensi determinasi $\left(R^{2}\right)$, pada intinya mengukur seberapa jauh kemampuan model dalam menerangkan variasi variabel dependen. Dalam hal ini $R$ Square digunakan untuk mengetahui seberapa jauh kemampuan tingkat pemahaman dalam menerangkan keputusan memilih fakultas ekonomi dan bisnis Islam. Nilai koefisiensi determinasi adalah 0 sampai 1, jika nilai $R^{2}$ kecil maka kemampuan variabel-variabel independen yang digunakan sangat terbatas. Sebaliknya ketika nilainya mendekati 1 , maka variabel independen yang digunakan mampu memberikan informasi yang dibutuhkan untuk memprediksi variabel dependen ${ }^{60}$.

\section{b. Uji Signifikansi Parameter Individual (Uji t)}

Uji $\mathrm{t}$ digunakan untuk mengetahui pengaruh variabel independen terhadap variabel dependen secara individual atau parsial dalam menerangkan variabel dependen. Uji t dilakukan dengan ujidua arah dengan hipotesis sebagai berikut ${ }^{61}$. Pengambilan keputusan dengan membandingkan hasil uji t hitung dengan $t$ tabel dan melihat nilai signifikansi ( $\alpha$ : 5\%), yaitu:

${ }^{60}$ Ghozali, Aplikasi Analisis Multivariate Dengan Program IBM SPSS 21: Update PLS Regresi..... h.97.

${ }^{61}$ Ghozali. Aplikasi Analisis Multivariate......, h. 99. 
Angrum Pratiwi: Pengaruh Tingkat Pemahaman Mahasiswa Terhadap Keputusan Memilih Jurusan Ekonomi dan Perbankan Syariah (Studi Perguruan Tinggi di Wilayah Kalimantan Timur)

1) Jika nilai $\mathrm{t}$ hitung $>\mathrm{t}$ tabel maka Ha diterima, artinya variabel independen berpengaruh terhadap variabel dependen secara parsial dan sebaliknya.

2) Jika nilai probabilitas (nilai signifikansi) $\leq 0,05$ jadi $\mathrm{H}_{0}$ ditolak, maka variabel independen berpengaruh terhadap variabel dependen.

\section{Hasil Penelitian}

\section{A. Karakteristik Responden}

\section{Asal Perguruan Tinggi}

Total responden penelitian ini berjumlah 448 responden yang tersebar di empat perguruan tinggi. Berdasarkan Gambar 4.1 menunjukkan bahwa $61 \%$ responden berasal dari FEBI IAIN Samarinda dan sebesar $23 \%$ responden berasal dari STAI Sangatta Kutai Timur. Sedangkan, responden yang berasal dari jurusan Ekonomi Syariah UNMUL berjumlah 13\% dari total keseluruan responden, dan STAI Ibnu Khaldun Balikpapan berjumlah $3 \%$.

\section{Gambar 4.1}

\section{Asal Perguruan Tinggi Responden}

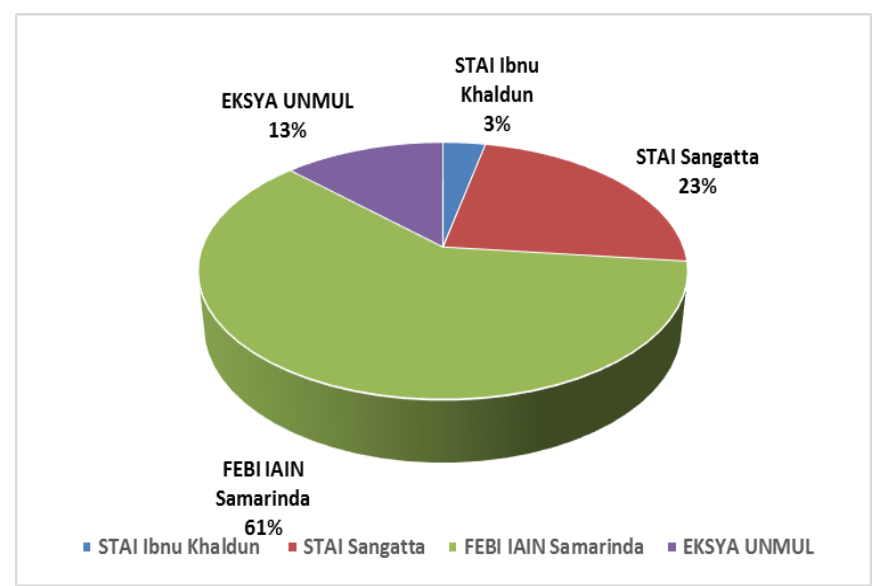

Sumber: Data primer diolah, 2019 
Angrum Pratiwi: Pengaruh Tingkat Pemahaman Mahasiswa Terhadap Keputusan Memilih Jurusan Ekonomi dan Perbankan Syariah (Studi Perguruan Tinggi di Wilayah Kalimantan Timur)

\section{Jurusan atau Program Studi Responden}

Berdasarkan hasil penelitian di lapangan, jurusan atau program studi yang sudah terlaksana di empat perguruan tinggi yaitu Ekonomi Syariah dan Perbankan Syariah. STAI Ibnu Khaldun Balikpapan, memiliki program studi Ekonomi Syariah dan juga Perbankan Syariah meskipun jumlah mahasiswa masih sangat sedikit. STAI Sangatta Kutai Timur memiliki jurusan Ekonomi Syariah di Fakultas Syariah dengan total mahasiswa aktif yaitu 463 orang. Sedangkan, Universitas Mulawarman memiliki jurusan Ekonomi Syariah di Fakultas Ekonomi dan Bisnis dengan jumlah sekitar 501 mahasiswa aktif, dan Fakultas Ekonomi dan Bisnis Islam IAIN Samarinda memiliki jurusan Ekonomi Syariah dan Perbankan Syariah dengan total mahasiswa aktif sekitar 1.100 orang. Gambar 4.2 menunjukkan bahwa, 32\% responden merupakan mahasiswa jurusan Perbankan Syariah dan $68 \%$ responden merupakan mahasiswa jurusan Ekonomi Syariah.

\section{Gambar 4.2}

Jurusan atau Prodi Responden

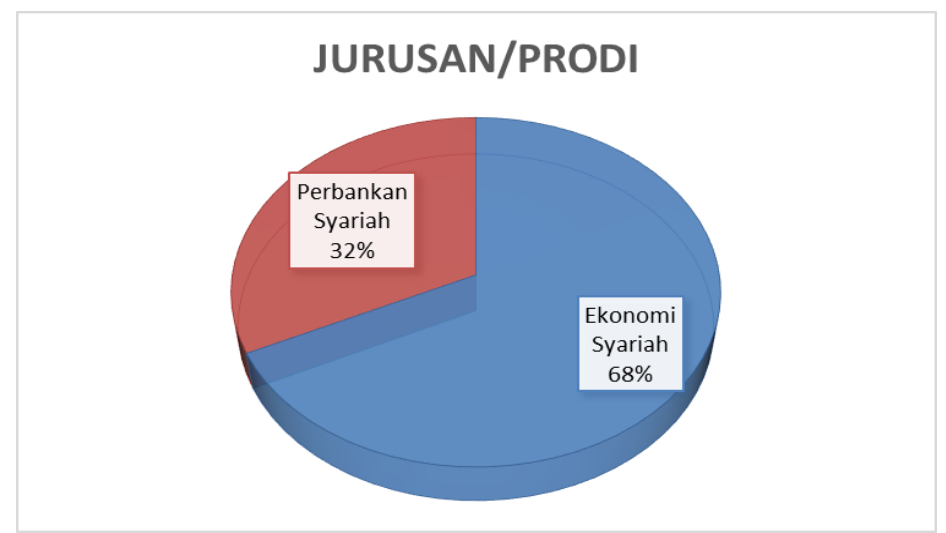

Sumber: Data primer diolah, 2019 
Angrum Pratiwi: Pengaruh Tingkat Pemahaman Mahasiswa Terhadap Keputusan Memilih Jurusan Ekonomi dan Perbankan Syariah (Studi Perguruan Tinggi di Wilayah Kalimantan Timur)

\section{Usia Responden}

Usia responden bervariasi terutama responden yang berasal dari STAI Ibnu Khaldun dan STAI Sangatta Kutai Timur karena sebagain besar mahasiswa sudah bekerja dan berumah tangga. Sedangkan untuk FEBI IAIN Samarinda dan UNMUL, usia responden berkisar 18-23 tahun yang masih duduk di semester III, IV, V, VI dan VII. Gambar 4.3 menunjukkan usia responden, dimana $82 \%$ masih didominasi usia 18-20 tahun.

\section{Gambar 4.3}

\section{Usia Responden}

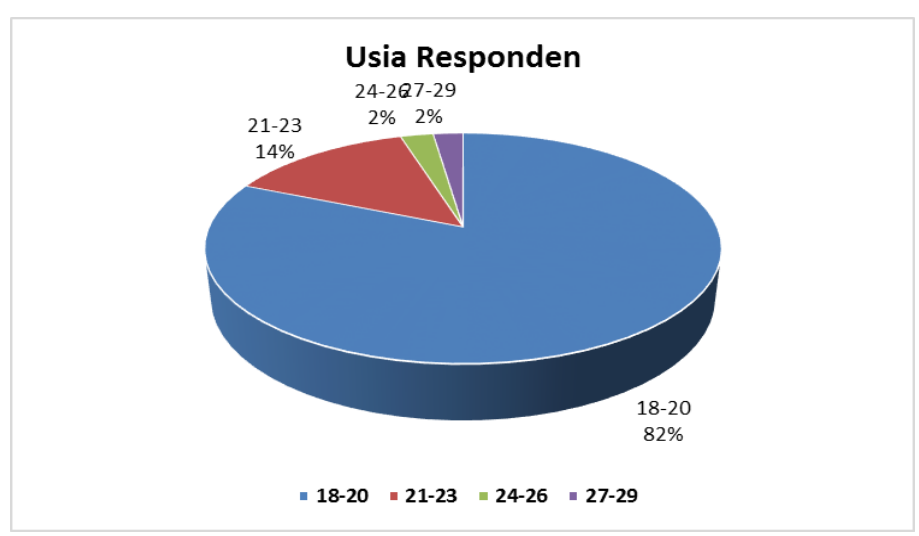

Sumber: Data Primer diolah, 2019

\section{Jenis Kelamin Responden}

Jenis kelamin responden mayoritas perempuan sebesar 55\%, sedangkan laki-laki sesbesar $45 \%$ dari total responden yang terkumpul. Mayoritas responden masih didominasi kaum hawa terutama jurusan Perbankan Syariah, karena ketertarikan perempuan untuk mengambil juruasn ini. 
Angrum Pratiwi: Pengaruh Tingkat Pemahaman Mahasiswa Terhadap Keputusan Memilih Jurusan Ekonomi dan Perbankan Syariah (Studi Perguruan Tinggi di Wilayah Kalimantan Timur)

Gambar 4.4

Jenis Kelamin Responden

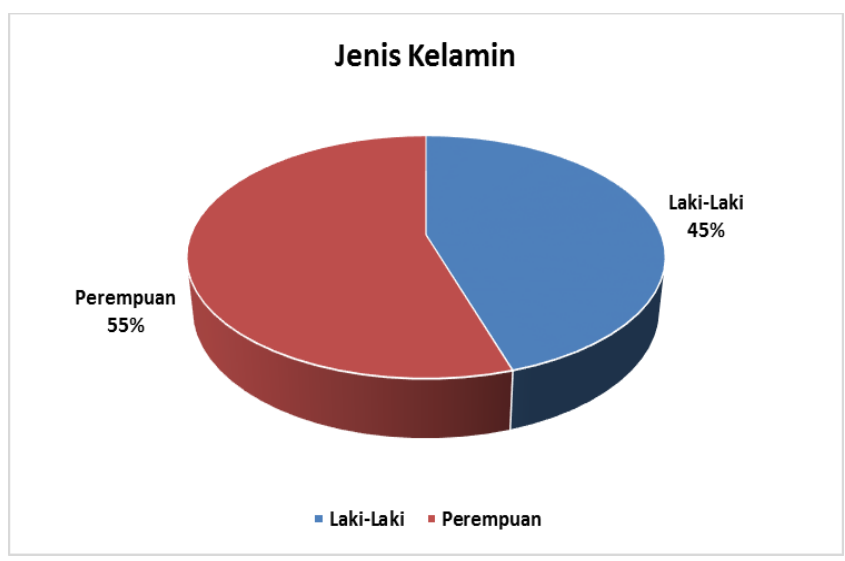

Sumber: Data primer diolah, 2019.

\section{B. Tingkat Pemahaman Mahasiswa}

Tingkat pemahaman mahasiswa tentang ekonomi Islam atau Perbankan Islam didapat dengan menyebarkan angket atau kuesioner ke empat perguruan tinggi yaitu STAI Ibnu Khaldun Balikpapan, STAI Sangatta Kutai Timur, Universitas Mulawarman, dan Institut Agama Islam Negeri Samarinda yang memiliki jurusan atau program studi Ekonomi Syariah atau Perbankan Syariah. Hasil kuesioner tingkat pemahaman dapat dilihat pada Tabel 4.1 di bawah ini:

\section{Tabel 4.1}

Hasil Kuesioner Tingkat Pemahaman Mahasiswa

\begin{tabular}{|c|c|c|c|c|c|c|c|c|c|c|c|c|}
\hline \multirow{2}{*}{ Ket } & \multicolumn{12}{|c|}{ Tingkat Pemahaman } \\
\hline & PEM1 & PEM2 & PEM3 & PEM4 & PEM5 & PEM6 & PEM7 & PEM8 & PEMg & PEM 10 & PEM11 & PEM 12 \\
\hline Rata2 & 4,63 & 4,27 & 3,86 & 3,78 & 3,57 & 3,38 & 3,47 & 3,51 & 2,84 & 3,28 & 3,91 & 4,00 \\
\hline Rata2Skor & \multicolumn{12}{|c|}{3,71} \\
\hline Tertinggi & \multicolumn{12}{|c|}{ Pertanyaan 1 (4,63) = Memahami agama Islam dengan baik dan menjalankan aturan agama Islam dengan sungguh-sungguh } \\
\hline Terendah & \multicolumn{12}{|c|}{ Pertanyaan $9(2,84)=$ Saya permah mengikuti Seminar/Workshop tentang Ekonomi dan Perbankan Islam } \\
\hline
\end{tabular}

Sumber: Data primer diolah, 2019 
Angrum Pratiwi: Pengaruh Tingkat Pemahaman Mahasiswa Terhadap Keputusan Memilih Jurusan Ekonomi dan Perbankan Syariah (Studi Perguruan Tinggi di Wilayah Kalimantan Timur)

Berdasarkan Tabel 4.1 menunjukkan bahwa hasil kuesioner variabel tingkat pemahaman dengan rata-rata tertinggi (skor 4,63) pada pertanyaan nomor pertama yaitu "Memahami agama Islam dengan baik dan menjalankan aturan agama Islam dengan sungguh-sungguh”. Artinya tingkat pemaham mahasiwa tentang agama Islam dan komitmen untuk manjalankan agama Islam dengan baik dan sungguh-sungguh sangat tinggi. Hal ini menjadi dasar mereka untuk mempelajari dan memahami ajaran agama Islam lainnya termasuk ekonomi atau perbankan Islam. Hasil kuesioner dengan skor terendah yaitu pada pertanyaan nomor sembilan (9), "saya pernah mengikuti workhop/seminar tentang ekonomi atau perbankan Islam”, artinya tingkat pemahaman yang tinggi tentang ekonomi atau perbankan Islam tidak diiringi dengan keterlibatan mahasiswa dalam seminar atau workshop ilmiah ekonomi atau perbankan Islam. Hasil kuesioner dengan skor rendah selanjutnya adalah pertanyaan nomor sepuluh (10), "Saya selalu meng-update pengetahuan tentang ekonomi syariah atau perbankan syariah". Tingkat literasi dan keinginan membaca mahasiswa masih tergolong rendah melihat hasil kuesioner pada pertanyaan 9 dan 10 . Perguruan tinggi sebagai wadah pengembangan keilmuan tentunya perlu mendukung mahasiswa untuk lebih aktif mengikuti atau menyelenggarakan seminar/workshop ekonomi atau perbankan Islam dalam rangka perluasan wawasan dan keilmuan.

Secara umum tingkat pemahaman mahasiswa tentang keagamaan dan pemahaman akan ekonomi atau perbankan Islam yang berasal dari empat perguruan tinggi di Kalimantan Timur masuk dalam kategori "cukup baik" dengan skor rata-rata 3,71. Pemahaman yang baiik tentunya menghasilkan keinginan atau keputusan untuk mempelajari dan turut mengembangkan ekonomi atau perbankan Isalm kedepan. Keterlibatan tenaga pendidik pada jurusan atau program studi dalam pengembangan keilmuan ekonomi atau perbankan Islam kiranya perlu ditingkatkan, dengan menghadirkan tenaga pendidik yang menguasai dengan baik materi yang akan disampaikan. 
Angrum Pratiwi: Pengaruh Tingkat Pemahaman Mahasiswa Terhadap Keputusan Memilih Jurusan Ekonomi dan Perbankan Syariah (Studi Perguruan Tinggi di Wilayah Kalimantan Timur)

\section{Hasil Uji Statistik Penelitian}

\section{Hasil Uji Reliabilitas dan Uji Validitas}

Uji reliabilitas kali ini menggunakan metode Alpha Cronbach, instrumen variabel dikatan reliabel jika nilai Alpha Cronbach >0,60. Tabel 4.2 menjukkan nilai Alpha Cronbach $(0,134)<0,60$, artinya instrumen variabel dikatakan tidak reliabel.

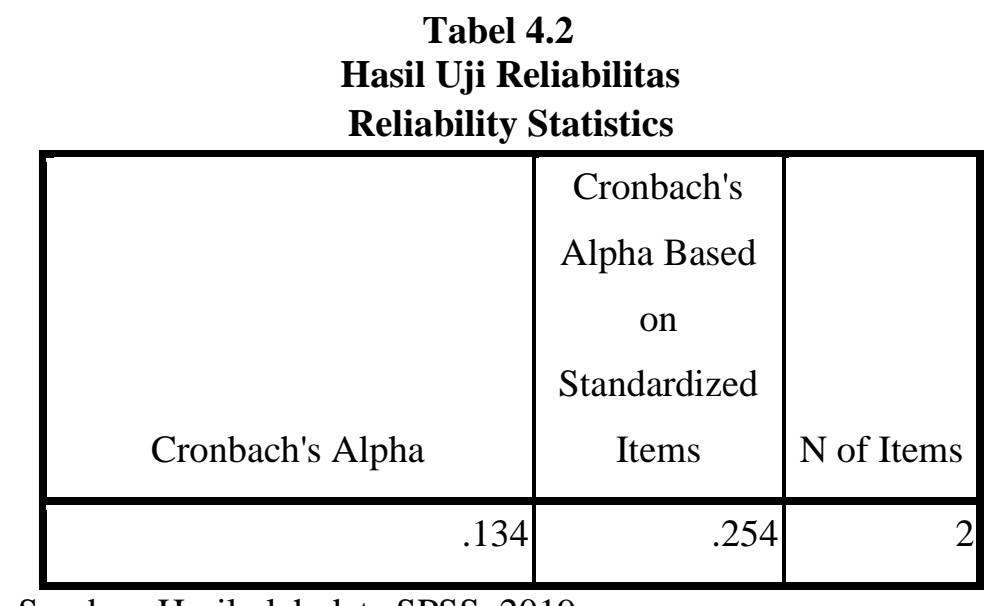

Sumber: Hasil olah data SPSS, 2019

Validitas adalah ketetapan atau kecermatan suatu instrument dalam mengukur apa yang diukur. Data dikatakan valid jika pertanyaan pada kuisoner mampu mengungkapkan sesuatu yang diukur oleh kuisoner tersebut. Tabel 4.3 menunjukkan hasil dari pearson correlation menunjukkan variabel tingkat pemahaman $0.100>0.05$ dan pearson correlation varibel keputusan signifikansi sebesar $0.145>0.05$, artinya kuesioner yang diajukan dinyatakan valid. 
Angrum Pratiwi: Pengaruh Tingkat Pemahaman Mahasiswa Terhadap Keputusan Memilih Jurusan Ekonomi dan Perbankan Syariah (Studi Perguruan Tinggi di Wilayah Kalimantan Timur)

Tabel 4.3

Hasil Uji Validitas

Correlations

\begin{tabular}{|ll|r|r|}
\hline & Pemahaman & Keputusan \\
\hline Pemahaman & Pearson Correlation & 1 & $.145^{* *}$ \\
& Sig. (2-tailed) & & .002 \\
& $\mathrm{~N}$ & 448 & 448 \\
\hline Keputusan & Pearson Correlation & $.145^{* *}$ & 1 \\
& Sig. (2-tailed) & .002 & \\
& $\mathrm{~N}$ & 448 & 448 \\
\hline
\end{tabular}

**. Correlation is significant at the 0.01 level (2-tailed).

Sumber: Hasil olah data SPSS, 2019.

\section{Hasil Uji Asumsi Klasik}

\section{a. Uji Normalitas}

Uji Normalitas, uji ini untuk menguji apakah dalam model regesi, uji ini menggunakan Kolmogrov Smirnov. Jika signifikan > 0,05 maka variabel berdistribusi normal. Tabel 4.4 menunjukkan hasil uji normalitas, dimana nilai signifikansi $0.102>0.05$ artinya data terdistribusi secara normal.

Tabel 4.4

Hasil Uji Normalitas

One-Sample Kolmogorov-Smirnov Test

\begin{tabular}{|l|r|}
\hline & $\begin{array}{c}\text { Unstandard } \\
\text { ized } \\
\text { Residual }\end{array}$ \\
\hline $\mathrm{N}$ & 448 \\
\hline Normal Parameters $^{\mathrm{a}} \quad$ Mean & .0000000 \\
\hline
\end{tabular}

Al Qalam: Jurnal Ilmiah Keagamaan dan Kemasyarakatan Vol. 13, No. 2, Juli-Desember 2019 
Angrum Pratiwi: Pengaruh Tingkat Pemahaman Mahasiswa Terhadap Keputusan Memilih Jurusan Ekonomi dan Perbankan Syariah (Studi Perguruan Tinggi di Wilayah Kalimantan Timur)

\begin{tabular}{|ll|r|}
\hline & Std. Deviation & .43953237 \\
\hline Most Extreme & Absolute & .089 \\
Differences & Positive & .046 \\
& Negative & -.089 \\
& & 1.891 \\
Kolmogorov-Smirnov Z & & .102 \\
Asymp. Sig. (2-tailed) & & \\
\hline
\end{tabular}

a. Test distribution is Normal.

Sumber: Hasil olah data SPSS, 2019.

\section{b. Uji Autokorelasi}

Mendeteksi autokorelasi dengan menggunakan nilai Durbin Watson. Suatu model regresi dinyatakan tidak terdapat permasalahan autokorelasi apabila nilai Durbin Watson (D-W) diantara $1-4$. Tabel 4.5 menunjukkan nilai D-W 1.728 diantara $1-4$, artinya tidak terdapat permasalan autokorelasi.

Tabel 4.5

\section{Hasil Uji Autokorelasi}

Model Summary

\begin{tabular}{|r|r|r|r|r|r|}
\hline Model & $\mathrm{R}$ & $\mathrm{R}$ Square & $\begin{array}{c}\text { Adjusted R } \\
\text { Square }\end{array}$ & $\begin{array}{c}\text { Std. Error of } \\
\text { the Estimate }\end{array}$ & $\begin{array}{c}\text { Durbin- } \\
\text { Watson }\end{array}$ \\
\hline 1 & $.145^{\mathrm{a}}$ & .021 & .019 & .4400 & 1.728 \\
\hline
\end{tabular}

a. Predictors: (Constant), Pemahaman

b. Dependent Variable: Keputusan

Sumber: Hasil olah data SPSS, 2019. 
Angrum Pratiwi: Pengaruh Tingkat Pemahaman Mahasiswa Terhadap Keputusan Memilih Jurusan Ekonomi dan Perbankan Syariah (Studi Perguruan Tinggi di Wilayah Kalimantan Timur)

\section{c. Uji Heteroskedastisitas}

Uji yang digunakan untuk melihat gejala ini menggunakan uji Glejser, hasilnya apabila nilai probabilitas signifikansinya lebih besar dari 5\% (>0,05), berarti tidak terjadi gejala heterokedastisitas. Tabel 4.6 menunjukkan hasil uji Glejser, dimana nilai probabilitas signifikansinya sebesar $0.119>0.05$ artinya tidak terjadi gejala heterokedastisitas.

Tabel 4.6

Hasil Uji Heterokedastisitas

Coefficients $^{\mathrm{a}}$

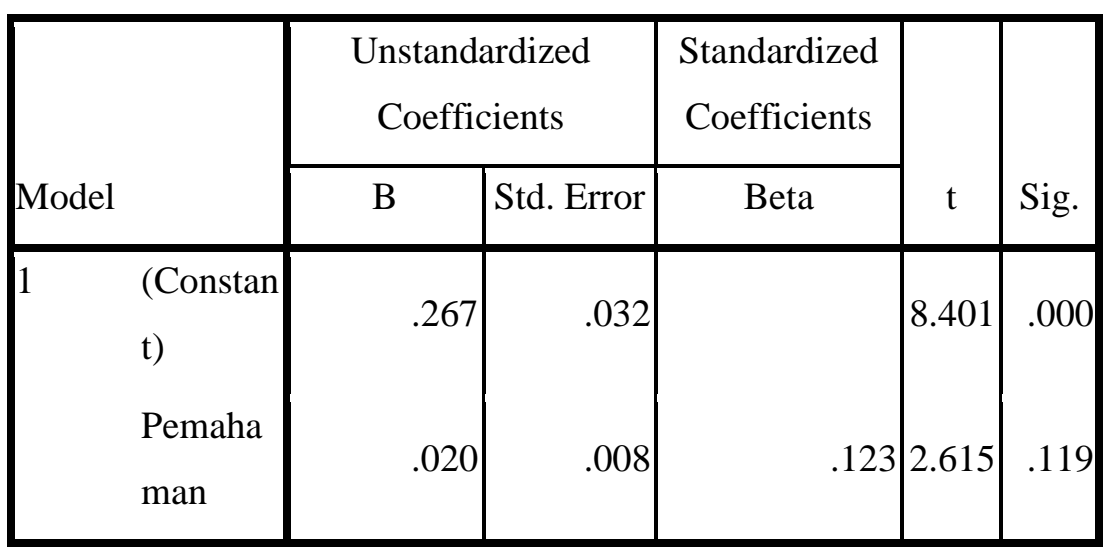

a. Dependent Variable:

ABSRes

Sumber: Hasil olah data SPSS, 2019.

\section{Analisis Regresi Linier Sederhana}

Analisis yang digunakan dalam penelitian ini adalah analisis regresi, yaitu suatu teknik yang digunakan untuk membangun suatu persamaan yang menghubungkan antara variabel terikat dengan variabel bebas sekaligus untuk menentukan nilai ramalan atau dugaan. Berdasarkan hasil olah data pada tabel 4.7 diperoleh model persamaan regresi linier sederhana dengan penjelasan sebagai berikut: 
Angrum Pratiwi: Pengaruh Tingkat Pemahaman Mahasiswa Terhadap Keputusan Memilih Jurusan Ekonomi dan Perbankan Syariah (Studi Perguruan Tinggi di Wilayah Kalimantan Timur)

$$
Y_{2}=\mathrm{a}+b_{2} \mathrm{X}+\mathrm{e}, \text { maka }
$$

Keputusan Memilih = 2,368 + 0,498 Tingkat Pemahaman $+\mathrm{e}$

Keterangan:

1) Konstanta (a) sebesar 2,368, menyatakan bahwa jika Tingkat Pemahaman bernilai 0, maka Keputusan Memilih akan sebesar $2,368 \%$.

2) Koefisien regresi Tingkat Pemahaman atau $X\left(b_{2}\right)$ sebesar 0,498 menunjukkan bahwa tingkat pemahaman berpengaruh positif terhadap keputusan memilih. Hal ini berarti bahwa, jika nilai tingkat pemahaman dinaikkan sebesar 1\%, maka akan menaikkan/meningkatkan keputusan memilih sebesar 0,498\%.

3) Standar error (e) menunjukkan tingkat kesalahan pengganggu yaitu sebesar 0.040 .

Tabel 4.7

Hasil Regresi Linier Sederhana Coefficients $^{\mathbf{a}}$

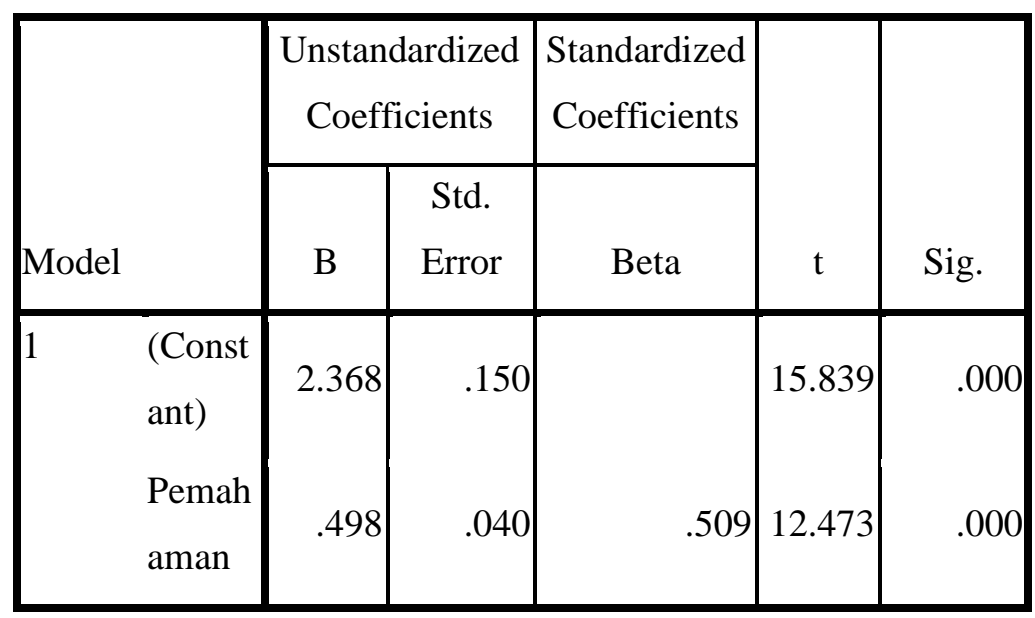

Sumber: Hasil olah data SPSS, 2019. 
Angrum Pratiwi: Pengaruh Tingkat Pemahaman Mahasiswa Terhadap Keputusan Memilih Jurusan Ekonomi dan Perbankan Syariah (Studi Perguruan Tinggi di Wilayah Kalimantan Timur)

\section{Hasil Uji Hipotesis}

\section{a. Hasil Uji Parsial (Uji t)}

Pengambilan keputusan dengan melihat nilai signifikansi $(\alpha$ : $5 \%$ ). Jika nilai probabilitas (nilai signifikansi) $\leq 0,05$, maka variabel independen berpengaruh terhadap variabel dependen. Tabel 4.8 menunjukkan bahwa nilai signifikansi sebesar 0.000 , artinya tingkat pemahaman berpengaruh signifikan terhadap keputusan mahasiswa memilih jurusan/program studi Ekonomi Syariah atau Perbankan Syariah pada perguruan tinggi di Kalimantan Timur.

Tabel 4.8

Hasil Uji t

Coefficients $^{\mathrm{a}}$

\begin{tabular}{|c|c|c|c|c|c|}
\hline \multirow[b]{2}{*}{ Model } & \multicolumn{2}{|c|}{$\begin{array}{l}\text { Unstandardized } \\
\text { Coefficients }\end{array}$} & \multirow{2}{*}{$\begin{array}{c}\text { Standardized } \\
\text { Coefficients } \\
\text { Beta }\end{array}$} & \multirow[b]{2}{*}{$\mathrm{t}$} & \multirow[b]{2}{*}{ Sig. } \\
\hline & B & $\begin{array}{l}\text { Std. } \\
\text { Error }\end{array}$ & & & \\
\hline $\begin{array}{l}1 \text { (Constan } \\
\text { t) } \\
\text { Pemaha } \\
\text { man }\end{array}$ & $\begin{array}{r}2.368 \\
.498\end{array}$ & .150 & .509 & 15.839 & $\begin{array}{l}.000 \\
.000\end{array}$ \\
\hline
\end{tabular}

a. Dependent Variable: Keputusan

Sumber: Hasil olah data SPSS, 2019.

\section{b. Hasil Uji Determinasi}

Koefisiensi Determinasi $\left(R^{2}\right)$, pada intinya mengukur seberapa jauh kemampuan model dalam menerangkan variasi variabel dependen. Dalam hal ini $R$ Square digunakan untuk mengetahui seberapa jauh kemampuan tingkat pemahaman (X) dalam 
Angrum Pratiwi: Pengaruh Tingkat Pemahaman Mahasiswa Terhadap Keputusan Memilih Jurusan Ekonomi dan Perbankan Syariah (Studi Perguruan Tinggi di Wilayah Kalimantan Timur)

menerangkan keputusan memilih (Y). Tabel 4.9 menunjukkan hasil $R$ Square yaitu 0.259 , artinya sebesar $25.9 \%$ tingkat pemahaman mahasiswa mampu menerangkan atau mempengaruhi keputusan memilih jurusan ekonomi atau perbankan Islam pada perguruan tinggi di Kalimantan Timur, sisanya $74.1 \%$ dipengaruhi oleh faktor lainnya yang tidak diteliti pada penelitian ini.

Tabel 4.9

Hasil Uji Determinasi

Model Summary

\begin{tabular}{|l|c|r|r|r|r|}
\hline Model & $\mathrm{R}$ & $\begin{array}{c}\mathrm{R} \\
\text { Square }\end{array}$ & $\begin{array}{c}\text { Adjusted R } \\
\text { Square }\end{array}$ & $\begin{array}{c}\text { Std. Error of } \\
\text { the Estimate }\end{array}$ & $\begin{array}{r}\text { Durbin- } \\
\text { Watson }\end{array}$ \\
\hline 1 & $.509^{\mathrm{a}}$ & .259 & .257 & .3839 & 1.667 \\
\hline
\end{tabular}

a. Predictors: (Constant),

Pemahaman

b. Dependent Variable: Keputusan

\section{Pembahasan Hasil Penelitian}

Proses pengambilan keputusan yang rumit sering melibatkan beberapa keputusan. Suatu keputusan melibatkan piliha diantara dua atau lebih alternatif tindakan. Keputusan selalu mensyaratkan pilihan diantara beberapa perilaku yang berbeda. Pengambilan keputusan merupakan bagian dari pemecahan masalah yang dihadapi oleh konsumen ${ }^{62}$.

Pemecahan masalah diawali dengan perbedaan yang dirasakan konsumen antara status ideal dengan status sebenarnya. Dalam hal ini konsumen merasa perlu mendapatkan pendidikan untuk meningkatkan pengetahuannya atau mengubah status sosialnya menjadi seorang Sarjana. Konsumen kemudian mencari informasi yang relevan dari lingkungan luar untuk memecahkan masalah yang dihadapinya, dengan meningkatkan

\footnotetext{
${ }^{62}$ Setiadi. Perilaku Konsumen ...., h. 413-414.
} 
Angrum Pratiwi: Pengaruh Tingkat Pemahaman Mahasiswa Terhadap Keputusan Memilih Jurusan Ekonomi dan Perbankan Syariah (Studi Perguruan Tinggi di Wilayah Kalimantan Timur)

pengetahuan dan ingatannya. Konsumen mencari informasi jurusan atau program studi dari beberapa perguruan tinggi untuk mendapatkan alternatif pilihan. Berdasarkan informasi, pengetahuan dan beberapa alternatif yang ditawarkan, konsumen akan memutuskan untuk memilih dari berbagai alternatif yang ditawarkan sesuai dengan kebutuhan konsumen ${ }^{63}$.

Pengambilan keputusan konsumen dalam membuat keputusan pembelian atau pemilihan dipengaruhi oleh faktor lingkungan, disamping tanggapan kognitif (pengetahuan) dan efektif yang diaktifkan selama proses pengambilan keputusan ${ }^{64}$. Hasil penelitian menunjukkan bahwa tingkat pemahaman berpengaruh positif dan siginifikan (Sig. 0.000) terhadap keputusan mahasiswa memilih jurusan/program studi ekonomi syariah atau perbankan syariah. Artinya hasil penelitian sejalan dengan teori yang telah dipaparkan sebelumnya bahwa keputusan konsumen untuk memilih atau membeli dipengaruhi oleh beberapa faktor yaitu lingkungan, informasi, dan pengetahuan yang didapat. Hasil penelitian sejalan dengan hasil penelitian terdahulu yang dilakukan oleh Mohammad dan Mustofa (2014), Mintarja, Wahab dan Masduki (2017), dan Hariyago dan Suprianto (2011), Umaryati (2017), dan Kartika (2017), menunjukkan variabel tingkat pemahaman berpengaruh terhadap pembelajaran mata kuliah tertentu, berpengaruh terhadap minat menabung, minat menjadi nasabah dan berpengaruh terhadap perilaku bisnis.

\section{Penutup}

\section{A. Kesimpulan}

1. Secara umum tingkat pemahaman mahasiswa tentang keagamaan dan pemahaman akan ekonomi atau perbankan Islam yang berasal dari empat perguruan tinggi di Kalimantan Timur masuk dalam kategori "cukup baik" dengan skor rata-rata 3,71. Pemahaman yang baiik

\footnotetext{
${ }^{63}$ Setiadi. Perilaku Konsumen ...., h. 417.

${ }^{64}$ Setiadi. Perilaku Konsumen ...., h. 425.
} 
Angrum Pratiwi: Pengaruh Tingkat Pemahaman Mahasiswa Terhadap Keputusan Memilih Jurusan Ekonomi dan Perbankan Syariah (Studi Perguruan Tinggi di Wilayah Kalimantan Timur)

tentunya menghasilkan keinginan atau keputusan untuk mempelajari dan turut mengembangkan ekonomi atau perbankan Isalm kedepan.

2. Hasil penelitian menunjukkan bahwa tingkat pemahaman berpengaruh positif dan siginifikan (Sig. 0.000) terhadap keputusan mahasiswa memilih jurusan/program studi ekonomi syariah atau perbankan syariah. Artinya hasil penelitian sejalan dengan teori yang telah dipaparkan sebelumnya bahwa keputusan konsumen untuk memilih atau membeli dipengaruhi oleh beberapa faktor yaitu lingkungan, informasi, dan pengetahuan yang didapat.

3. Hasil uji determinasi menunjukkan hasil $R$ Square yaitu sebesar 0.259, artinya sebesar $25.9 \%$ tingkat pemahaman mahasiswa mampu menerangkan atau mempengaruhi keputusan memilih jurusan ekonomi atau perbankan Islam pada perguruan tinggi di Kalimantan Timur, sisanya $74.1 \%$ dipengaruhi oleh faktor lainnya yang tidak diteliti pada penelitian ini.

\section{B. Saran Penelitian}

Saran penelitian bagi perguruan tinggi yang menyelenggarakan jurusan atau program studi ekonomi syariah atau perbankan syariah, untuk lebih meningkatkan literasi dalam bentuk workshop/seminar tentang ekonomi atau perbankan Islam guna menambah wawasan dan pengetahuan mahasiswa. Meningkatkan kapasitas keilmuan tenaga pendidik untuk mendukung kegiatan belajar dalam pengembangan literasi tentang ekonomi atau perbankan syariah. Peran dan sumbangsih perguruan tinggi untuk mencetak sumber daya insani yang memahami ekonomi syariah atau perbankan syariah, tentunya menjadi daya tarik masyarakat untuk menjadikan perguruan tinggi pilihan terbaik dalam pendidikan.

Saran untuk peneliti selanjutnya yaitu menambah variabel lainnya yang secara teori mempengaruhi keputusan konsumen, seperti adanya iklan, informasi, pengetahuan, faktor lingkungan, faktor budaya dan lainnya. 
Angrum Pratiwi: Pengaruh Tingkat Pemahaman Mahasiswa Terhadap Keputusan Memilih Jurusan Ekonomi dan Perbankan Syariah (Studi Perguruan Tinggi di Wilayah Kalimantan Timur)

Sehingga, hasil penelitian bisa disimpulkan lebih mendalam dan mampu menjelaskan faktor lain yang mempengaruhi keputusan konsumen. 
Angrum Pratiwi: Pengaruh Tingkat Pemahaman Mahasiswa Terhadap Keputusan Memilih Jurusan Ekonomi dan Perbankan Syariah (Studi Perguruan Tinggi di Wilayah Kalimantan Timur)

\section{Daftar Pustaka}

Antonio, Muhammad Syafi'i. Ekonomi Islam. Bogor: STEI TAZKIA, 2010.

Dahlia, Staf Akademik. Jumlah Mahasiswa Aktif. Tertulis, 24 Mei 2019. FEBI IAIN Samarinda.

Damiati, dkk. Perilaku Konsumen. Jakarta: PT. RajaGrafindo Persada, 2017.

Firdaus, Staf Akademik. Sistem Perkuliahan dan Jumlah Mahasiswa Aktif. Tertulis, 13 Mei 2019. STAI Sangatta Kutai Timur.

Ghozali, Imam. Aplikasi Analisis Multivariate Dengan Program IBM SPSS 21:

Update PLS Regresi. 7 ed. Semarang: Badan Penerbit UNDIP, 2013.

Hariyoga, Septian, dan Edy Suprianto. "Pengaruh Kecerdasan Emosional, Perilaku Belajar, dan Budaya terhadap Tingkat Pemahaman Akuntansi Dengan Kepercayaan Diri sebagai Variabel Pemoderasi.” Simposium Akuntansi Nasional XIV Aceh, no. 14 (Juli 2011): 1-28.

Ibu Marwah, Ketua Yayasan. Jumlah Mahasiswa Aktif Jurusan/Prodi Ekonomi atau Perbankan Syariah. Tertulis, 17 Mei 2019. STAI Ibnu Khaldun Balikpapan.

Isna Yuningsih, KaProdi EKIS. Jumlah Mahasiswa Prodi Ekonomi Islam. Online-WhatsApp, 27 Mei 2019. FEB UNMUL.

Kanwil BI Provinsi Kalimantan Timur. "Kajian Ekonomi dan Keuangan Regional Kalimantan Timur.” Ekonomi dan Keuangan. Samarinda: Bank Indonesia, Februari 2019.

Karim, Adimarwan A. Ekonomi Mikro Islami. Jakarta: PT. RajaGrafindo Persada, 2007.

Karim, Adiwarman A. Bank Islam: Analisis Fiqih \& Keuangan. 4 ed. Jakarta: PT. RajaGrafindo Persada, 2010.

Kartika, Dewi. "Pengaruh Pemahaman Mahasiswa Perbankan Syariah Atas Bagi Hasil Dan Bunga Terhadap Minat Menjadi Nasabah Bank Syariah 
Angrum Pratiwi: Pengaruh Tingkat Pemahaman Mahasiswa Terhadap Keputusan Memilih Jurusan Ekonomi dan Perbankan Syariah (Studi Perguruan Tinggi di Wilayah Kalimantan Timur)

Studi Kasus Mahasiswa Perbankan Syariah IAIN Surakarta Angkatan 2014-2016.” Skripsi, IAIN Surakarta, 2017.

Mintarja, Endang, Ahsin Abdul Wahab, dan Uki Masduki. "Hubungan Pengajaran Mata Kuliah Ekonomi Islam terhadap Minat Mahasiswa Menabung di Bank Syariah." Hayula: Indonesian Journal of Multidisciplinary Islamic Studies 1, no. 2 (Juli 2017): 189-208. https://doi.org/10.21009/hayula.001.2.04.

Manap, Abdul. Revolusi Manajemen Pemasaran. 1 ed. Jakarta: Mitra Wacana Media, 2016.

Mohammad, Roni, dan Mustofa. "Pengaruh Tngkat Pemahaman Agama Terhadap Perilaku Bisnis Pedagang Pasar Minggu Telaga Kab. GorontaloP.” Jurnal Al-Mizan Vol. 10, no. No. 1 (Juni 2014).

Nopirin. Pengantar Ilmu Ekonomi: Makro dan Mikro. 13 ed. Yogyakarta: BPFE, 2016.

Novius, Andri. "Analisis Pemahaman Mahasiswa Akuntansi Dalam Menghadapi Mata Kuliah Dasar-Dasar Akuntansi: Studi pada Mahasiswa Akuntansi S1- UIN Sultan Syarif Kasim Riau.” Fokus Ekonomi Vol. 5, no. 2 (Desember 2010): 44-60.

Presiden Republik Indonesia. "Undang-Undang Republik Indonesia No. 12 Tahun 2012 Tentang Pendidikan Tinggi.” Republik Indonesia, 2012. Jakarta.

Putra, Purnama. "Analisis Tingkat Pemahaman Mahasiswa Terhadap Pernyataan Standar Akuntansi Keuangan Syariah PSAK - Syariah.” JRAK Vol. 6, no. No. 1 (Februari 2015): 38-50.

Rangkuti, Freddy. Customer Care Excellence: Meningkatkan Kinerja Perusahaan melalui Pelayanan Prima. Jakarta: PT. Gramedia Pustaka Utama, 2016.

Setiadi, Nugroho J. Perilaku Konsumen: Konsep dan Implikasi untu Strategis dan Penelitian Pemasaran. 1 ed. Jakarta: Kencana, 2005. 
Angrum Pratiwi: Pengaruh Tingkat Pemahaman Mahasiswa Terhadap Keputusan Memilih Jurusan Ekonomi dan Perbankan Syariah (Studi Perguruan Tinggi di Wilayah Kalimantan Timur)

Sugiyono. Metode Penelitian Kuantitatif, Kualitatif dan $R \&$ D. 17 ed. Bandung: Alfabeta, 2012.

Sugiyono. Metode Penelitian Kuantitatif, Kualitatif dan $R \&$ D. 17 ed. Bandung: Alfabeta, 2012.

_. Metode Penelitian Manajemen. 4 ed. Bandung: Alfabeta, 2015.

Sujarweni, V. Wiratna. Kupas Tuntas Penelitian Akuntansi Dengan SPSS. Yogyakarta: Pustaka Baru Pers, 2016.

Suliyanto. Metode Penelitian Bisnis: Untuk Skripsi, Tesis dan Desertasi. Yogyakarta: ANDI, 2018.

Suliyanto. Ekonometrika Terapan: Teori \& Aplikasi dengan SPSS. Yogyakarta: ANDI, 2011.

- Metode Penelitian Bisnis: Untuk Skripsi, Tesis dan Desertasi. Yogyakarta: ANDI, 2018.

Tim Penyusun Pusat Bahasa. "Kamus Bahasa Indonesia.” Jakarta: Departemen Pendidikan Nasional, 2008.

Umaryati, Siti. "Pengaruh Pembelajaran Ekonomi Islam terhadap Minat Mahasiswa Menabung di Bank Syariah (Studi pada Mahasiswa IPS UIN Syarif Hidayatullah Jakarta).” Skripsi, UIN Syarif Hidayatullah, 2017.

“Undang-Undang No. 21 Tahun 2008 Tentang Perbankan Syariah.” Republik Indonesia, 2008.

\section{Website:}

Admin. "Profil FEBI IAIN Samarinda." Www.febi.iain-samarinda.ac.id, 27 April 2015.

—. "Profil S1 Program Studi Ekonomi Islam." Www.fe.unmul.ac.id, 5 Januari 2019.

_ . "Profil Sekolah Tinggi Agama Islam Sangatta (STAIS) Kutai Timur." Http://www.staiskutim.ac.id, 22 Maret 2015. 
Angrum Pratiwi: Pengaruh Tingkat Pemahaman Mahasiswa Terhadap Keputusan Memilih Jurusan Ekonomi dan Perbankan Syariah (Studi Perguruan Tinggi di Wilayah Kalimantan Timur)

-. "STAI Ibnu Khaldun Balikpapan Kalimantan Timur Profil dan Program Studi.” www.madinatuliman.com, 14 Juli 2018. 